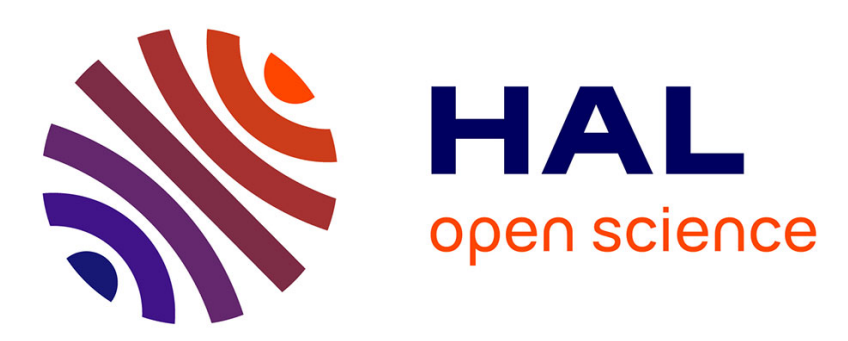

\title{
Practical Chromatography-Free Synthesis of 2-Iodo-N,N-diisopropylferrocenecarboxamide and Further Transformations
}

William Erb, Thierry Roisnel, Vincent Dorcet

\section{To cite this version:}

William Erb, Thierry Roisnel, Vincent Dorcet. Practical Chromatography-Free Synthesis of 2-IodoN,N-diisopropylferrocenecarboxamide and Further Transformations. Synthesis: Journal of Synthetic Organic Chemistry, 2019, 51 (17), pp.3205-3213. 10.1055/s-0039-1689917 . hal-02303395

\section{HAL Id: hal-02303395}

\section{https://hal-univ-rennes1.archives-ouvertes.fr/hal-02303395}

Submitted on 18 Nov 2019

HAL is a multi-disciplinary open access archive for the deposit and dissemination of scientific research documents, whether they are published or not. The documents may come from teaching and research institutions in France or abroad, or from public or private research centers.
L'archive ouverte pluridisciplinaire HAL, est destinée au dépôt et à la diffusion de documents scientifiques de niveau recherche, publiés ou non, émanant des établissements d'enseignement et de recherche français ou étrangers, des laboratoires publics ou privés. 


\section{Practical chromatography-free synthesis of 2-iodo- $\mathrm{N}, \mathrm{N}$-diisopropyl- ferrocenecarboxamide and further transformations}

\author{
William Erb* \\ Thierry Roisnel \\ Vincent Dorcet \\ Univ Rennes, CNRS, ISCR (Institut des Sciences Chimiques de \\ Rennes) - UMR 6226, F-35000 Rennes, France. \\ william.erb@univ-rennes1.fr
}

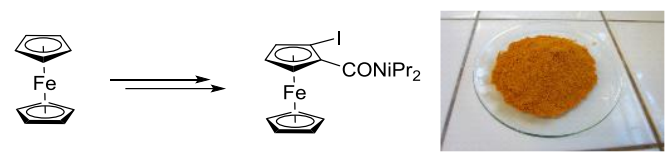

3-Step synthesis
$79 \%$ overall yield
$36 \mathrm{~g}$ prepared in a single batch
Further functionalization possible
Abstract An efficient procedure able to deliver grams of racemic and enantioenriched 2-iodo- $N, N$-diisopropylferrocenecarboxamide without chromatographic purification was developed. To introduce the halogen, two procedures, one using the $n$ BuLi-TMEDA chelate and one using a lithium amide in the presence of $\mathrm{ZnCl}_{2}$ as in situ trap were developed. Further functionalization by Suzuki-Miyaura and Ullman-type cross-couplings was investigated to access a variety of ferrocene derivatives.

Key words Ferrocene, carboxamide, large scale synthesis, deprotometalation, Suzuki-Miyaura cross-coupling, Ullmann-type cross-coupling

Discovered in 1951, ferrocene is currently one of the most important organometallic scaffolds with multiple applications in redox sensing, catalysis, materials science and medicinal chemistry. ${ }^{1}$ Due to its planar chirality when two different substituents are located on the same ring of a ferrocene, the search for asymmetric syntheses has been a recurring question in metallocene science. ${ }^{2}$ The diastereoselective orthodeprotometalation $(\mathrm{Do} \mathrm{M})$ is a powerful methodology but implies multiple steps to install and remove, when possible, the chiral directing group. Therefore, only a few directing groups are usually used in this strategy. ${ }^{3}$ Enzymatic and chemical kinetic resolution have been investigated with various levels of success but are not general. ${ }^{4}$ Recent years have witnessed the emergence of catalytic asymmetric ferrocene $\mathrm{C}-\mathrm{H}$ bond activation. ${ }^{5}$ However, due to the use of an expensive catalytic system and, although growing, still limited functionalization scope, this approach remains limited. The enantioselective DoM of monosubstituted ferrocenes is another approach which relies on the ability of a chiral base to discriminate between both enantiotopic protons. Although various substrates have been evaluated over the years, ${ }^{6}$ $N, N$-diisopropylferrocenecarboxamide (1) afforded the best results when treated with the $n \mathrm{BuLi}-(-)$-sparteine chelate before interception with an electrophile. ${ }^{7}$ Even if the availability and prices of sparteine enantiomers have varied over time, (+)sparteine has remained the most expensive for a long period. ${ }^{8}$ Therefore, the use of O'Brien's (+)-sparteine surrogate was required to deliver the opposite enantiomer of 2-substituted ferrocenecarboxamide with high level of stereocontrol. ${ }^{9}$ It should be pointed out that, though $\mathbf{1}$ has mainly been functionalized by deprotolithiation, its deproto-mercuration, ${ }^{10}$-cupration ${ }^{11}$ and zincation ${ }^{12}$ have also be reported to prepare compounds that are otherwise hardly accessible.

In the frame of our ongoing research program dedicated to the synthesis of original ferrocene derivatives, ${ }^{13}$ we required large quantities of 2-iodo- $N, N$-diisopropylferrocenecarboxamide (2) in both racemic and enantioenriched forms. Although already reported in the literature, the protocols relying on chromatographic purification were not compatible with the scale required here.

Here we describe the chromatography-free large scale synthesis of $( \pm)-2$ and the gram-scale synthesis of $\left(\boldsymbol{S}_{p}\right)$-2 (Scheme 1). The usefulness of $\mathbf{2}$ in organic synthesis was further demonstrated by its functionalization through palladium-catalyzed SuzukiMiyaura and copper-mediated Ullmann-type cross-couplings.

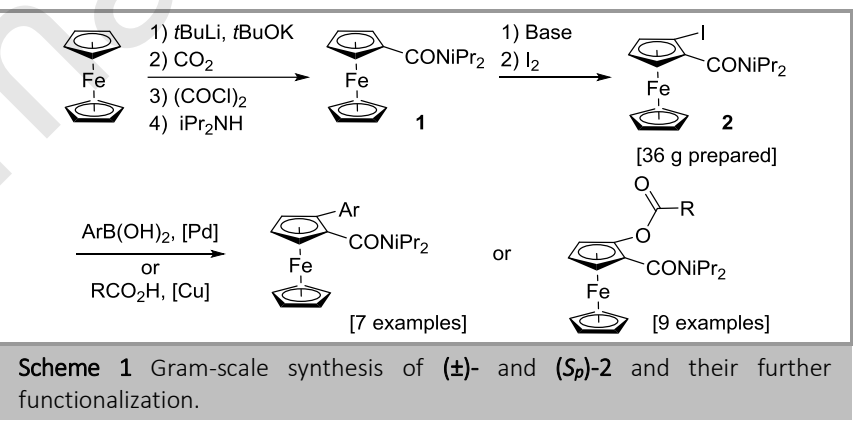

Commercially available ferrocenecarboxylic acid (3) remaining expensive, our synthesis starts from ferrocene, which is metallated using an excess of $t \mathrm{BuLi}$ in the presence of a catalytic amount of $t \mathrm{BuOK}$, as described by Mueller-Westerhoff (Scheme 2). ${ }^{14}$ Upon metallation completion, gaseous carbon dioxide is passed through the reaction mixture to afford, after acidic workup, ferrocenecarboxylic acid (3) in 94\% yield (34 g in a single batch). It was subsequently converted into $\mathrm{N}, \mathrm{N}$ diisopropylferrocenecarboxamide (1) by a two-step process: formation of the acyl chloride by treatment with an excess of oxalyl chloride in the presence of catalytic amounts of dimethylformamide (DMF) and reaction with diisopropylamine. In our optimized protocol, which does not require anhydrous conditions, the crude product can be obtained in a couple of hours. Usually purified by column chromatography, we found that a simple recrystallization of the crude reaction mixture from heptane affords analytically pure product in 95.5\% yield. Racemic deprotometalation of compound $\mathbf{1}$ can be performed using $n \mathrm{BuLi}$ in the presence of $N, N, N^{\prime}, N^{\prime}$ tetramethylethylenediamine (TMEDA) to enhance its reactivity in diethyl ether. We briefly studied the possibility to carry out this transformation with the more reactive $s \mathrm{BuLi}$ in THF at $-78^{\circ} \mathrm{C}$; 
however, moderate yields (68\% on average), resulting from the formation of multiple by-products, were obtained. Therefore, the deprotometalation with the $n$ BuLi-TMEDA chelate in diethyl ether at cryogenic temperature was performed, followed by iodine interception. After a traditional work-up and removal of insoluble by-products, a simple recrystallization allowed the isolation of $36 \mathrm{~g}$ of the title product $( \pm)-2$ in a single batch (88\% yield).

For practical reasons, we have also developed another large scale synthesis of $(\mathbf{\pm})-\mathbf{2}$ by following the in situ trapping strategy. ${ }^{15}$ Therefore, we reacted 1 with LiTMP (TMP $=2,2,6,6$ tetramethylpiperidide) in the presence of anhydrous $\mathrm{ZnCl}_{2}$ as the in situ trap in THF before interception with iodine. By following a similar work-up and crystallization purification protocol, we isolated $20 \mathrm{~g}$ of $(\mathbf{\pm})-2$ in a single batch (93\% yield).

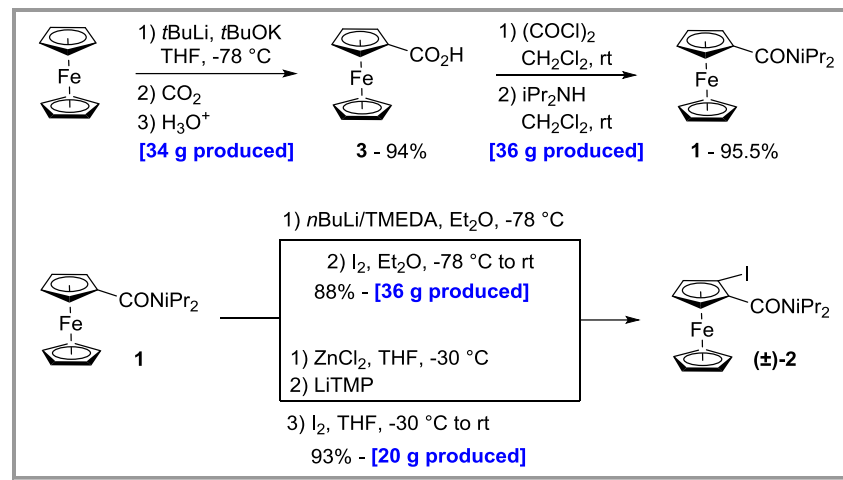

Scheme 2 Column chromatography-free multi-gram synthesis of compound $( \pm)-2$.

Having established a reliable multi-gram access toward ( $\mathbf{\pm}$ )-2, we turned our attention to its enantioenriched form. As the use of O'Brien's (+)-sparteine surrogate has not yet been attempted on 1, we thought it interesting to secure this way. However, and even though (+)-sparteine surrogate is easily available from natural sources, ${ }^{16}$ performing the asymmetric deprotometalation of $\mathbf{1}$ at a scale similar to that of the racemic one was economically not viable. By following $\mathrm{O}^{\prime}$ Brien's protocol, ${ }^{9}$ we therefore prepared $1.4 \mathrm{~g}$ of $\left(\boldsymbol{S}_{\boldsymbol{p}}\right)-\mathbf{2}$ (69\% yield) with an enantiomeric ratio (er) of $96: 4$ as determined by chiral HPLC (Scheme 3). Interestingly, a simple recrystallization increases the er up to 99:1. Initially inferred by optical rotation measurement, the absolute configuration of $\left(\boldsymbol{S}_{\boldsymbol{p}}\right)$ 2 was confirmed by X-ray diffraction analysis (see SI).

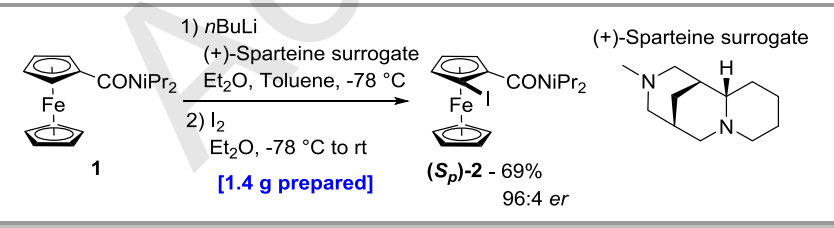

Scheme 3 Enantioselective synthesis of compound $\left(S_{p}\right)-2$.

Therefore, assuming that (-)-sparteine or (+)-sparteine surrogate are accessible in sufficient quantities, ten or so grams of the enantioenriched ferrocene $\mathbf{2}$ can be prepared in a few days without recurring to chromatographic purification. This is especially relevant with the $(+)$-sparteine surrogate which can be used in catalytic amount without major drop in the er.

Although we previously demonstrated the usefulness of $\mathbf{2}$ to access original 3-iodo- $N, N$-diisopropylferrocenecarboxamide through a halogen 'dance' reaction, ${ }^{13,}, 17$ the functionalization of the former was not extensively studied. In 2014, Kumar has reported an original example of a $t \mathrm{BuOK}$-mediated $\mathrm{sp}^{3} \mathrm{C}-\mathrm{H}$ bond functionalization to access lactams in $96 \%$ yield from ( \pm )-2.18 Earlier, Snieckus showed that the Suzuki-Miyaura cross-coupling of $\left(\boldsymbol{R}_{\boldsymbol{p}}\right) \mathbf{- 2}$ under aqueous conditions afforded the desired biaryl product in low yield but with unchanged enantiomeric ratio (31\% yield, 98:2 er). ${ }^{7}$ More recently, Anderson showed the ability of $\mathrm{Cu}_{2} \mathrm{O}$ to perform an Ullmann-type cross-coupling between $\left(\boldsymbol{R}_{p}\right)$-2 and either phthalimide or acetic acid. ${ }^{19}$ The positive optical rotation recorded clearly indicated that enantioenriched products were obtained but without further indication of the enantiomeric ratio.

Therefore, we thought it interesting to apply Suzuki-Miyaura reaction conditions able to deliver the desired products in higher yields. The full transfer of chiral information being already reported, we focussed our study on racemic compounds. As aqueous reaction conditions seem to promote dehalogenation instead of the desired coupling reaction on such substrates, we successfully switched to anhydrous conditions. Therefore, reacting ( $\mathbf{\pm}$-2 2 with phenylboronic acid in the presence of $\mathrm{Pd}(\mathrm{dba})_{2}(\mathrm{dba}=$ dibenzylideneacetone $), \mathrm{PPh}_{3}$ and $\mathrm{CsF}$ in toluene smoothly afforded the title product ( \pm )-4 in 58\% yield (Scheme 4). Following the general reactivity trend of boronic acids in the Suzuki-Miyaura cross-coupling, ${ }^{20}$ the electron-rich ones afforded higher yields (compounds ( $\mathbf{\pm}$ )-5-7), while a major yield drop was noticed with the chlorinated and trifluoromethylated ones (compounds ( $\mathbf{\pm}$ )-8-10). In these cases, moderate conversions as well as competitive dehalogenation were noticed. The use of ferroceneboronic acid, ${ }^{21}$ 2-thienylboronic acid or 4nitrophenylboronic acid only led to recovery of starting material or degradation.

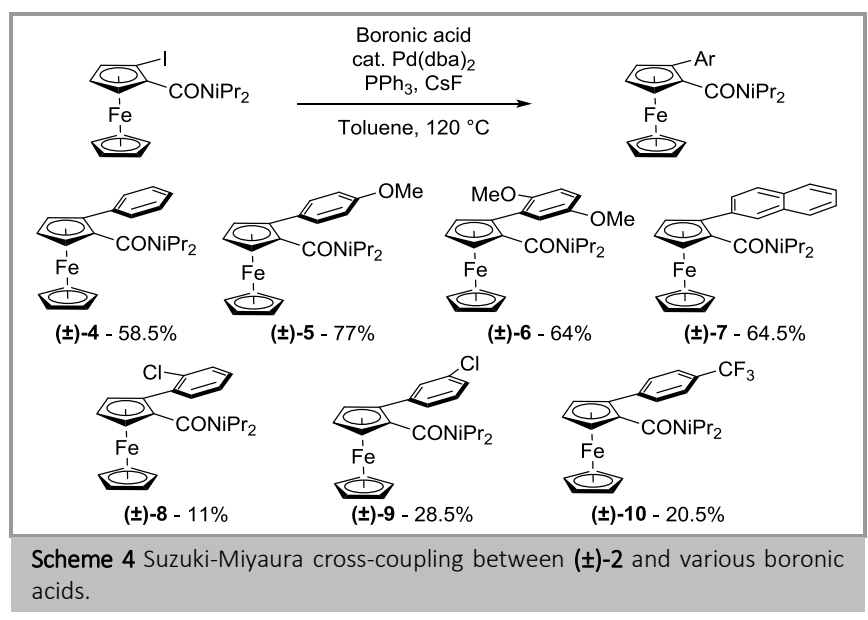

Advanced NMR studies and X-ray diffraction analyses revealed similar structures in solution and in the solid state, probably due to the reduced degree of freedom for steric reasons (see SI). As a result, all peaks of the ${ }^{1} \mathrm{H}$ NMR spectra of compounds $(\mathbf{\pm})-4-10$ are well resolved while the isopropyl signals are usually broad singlets in the ferrocenecarboxamide series. In all studied cases, the phenyl ring appears tilted relative to the $\mathrm{Cp}$ ring while the $\mathrm{C}=\mathrm{O}$ bond of the amide always points down toward the iron atom. Furthermore, one methyl of each isopropyl group points toward the aromatic ring while the other points toward the ferrocene 
moiety. Depending on the substituent on the phenyl ring, some degree of rotation around the FcC-ArC bond was noticed.

To complete this study, we finally extended the scope of the copper-mediated C-0 bond formation between $\mathbf{2}$ and carboxylic acids. When reacting ( $\mathbf{\pm})-\mathbf{2}$ with a slight excess of 4-fluorobenzoic acid in the presence of $\mathrm{Cu}_{2} \mathrm{O}$, we isolated $(\mathbf{\pm})-\mathbf{1 1}$ in $85 \%$ yield (Scheme 5). Similarly, from $\left(\boldsymbol{S}_{\boldsymbol{p}}\right)-\mathbf{2}$ (87:13 er), $\left(\boldsymbol{S}_{\boldsymbol{p}}\right)$-11 was obtained in 76\% yield and almost unchanged er ratio (89:11). Having established the full transfer of chiral information, we evaluated the reaction between ( $\mathbf{\pm}$-2 2 and other coupling partners. 2-Naphthoic, 2,4-dimethylbenzoic and 2acetoxybenzoic acids all afforded the corresponding esters $(\mathbf{\pm})$ 12-14 in good yields while terephthalic acid led to the bis-ester ( \pm )-15 in 49\% yield. The reaction was also found to be compatible with ferrocenecarboxylic and 2-thiophenecarboxylic

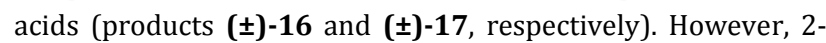
picolinic acid and phenylpropiolic acids only led to recovery of starting material. Finally, acrylic acid derivatives such as 3,4methylenedioxycinnamic acid and piperic acid were successfully converted into the corresponding esters $(\mathbf{\pm})-\mathbf{1 8}$ and $(\mathbf{\pm})-\mathbf{1 9}(88 \%$ and $92 \%$ yield, respectively).

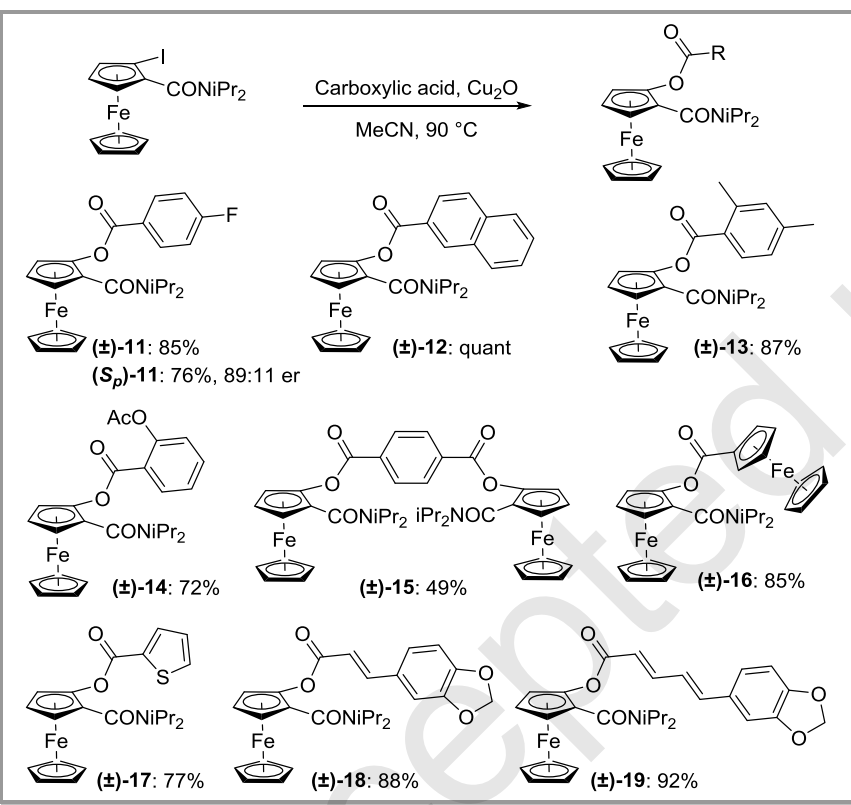

Scheme 5 Ullmann-type cross-coupling between $( \pm)-2$ or $\left(S_{p}\right)-2$ and various carboxylic acids.

In conclusion, we have reported reaction conditions able to deliver grams of 2-iodo- $N, N$-diisopropylferrocenecarboxamide $( \pm)$ - or $\left(\boldsymbol{S}_{\boldsymbol{p}}\right)$-2 from cheap ferrocene without chromatographic purification. Two protocols, one using the $n$ BuLi-TMEDA chelate and one using LiTMP in the presence of $\mathrm{ZnCl}_{2}$ as an in situ trap were therefore successfully developed. Further elaboration through Suzuki-Miyaura or Ullmann-type cross-coupling reactions afforded biarylic and ester derivatives in moderate to good yields.

General Considerations. Unless otherwise stated, all the reactions were performed under an argon atmosphere with anhydrous solvents using Schlenk technics. THF and $\mathrm{Et}_{2} \mathrm{O}$ were distilled over sodiumbenzophenone, acetonitrile and toluene were distilled over $\mathrm{CaH}_{2}$. Unless otherwise stated, all reagents were used without prior purification. All organolithiated reagents were titrated before use. ${ }^{22}$ tBuOK $(99.99 \%$ quality) was purchased from Sigma-Aldrich and used without further purification. Column chromatography separations were achieved on silica gel $(40-63 \mu \mathrm{m})$. All Thin Layer Chromatographies (TLC) were performed on aluminum backed plates pre-coated with silica gel (Merck, Silica Gel 60 F254). They were visualized by exposure to UV light. Melting points were measured on a Kofler bench. IR spectra were taken on a Perkin-Elmer Spectrum 100 spectrometer. ${ }^{1} \mathrm{H}$ and ${ }^{13} \mathrm{C}$ Nuclear Magnetic Resonance (NMR) spectra were recorded either (i) on a Bruker Avance III spectrometer at $300 \mathrm{MHz}$ and $75.4 \mathrm{MHz}$, respectively, or (iii) on a Bruker Avance III $\mathrm{HD}$ at $500 \mathrm{MHz}$ and $126 \mathrm{MHz}$, respectively. ${ }^{1} \mathrm{H}$ chemical shifts $(\delta)$ are given in ppm relative to the solvent residual peak and ${ }^{13} \mathrm{C}$ chemical shifts are relative to the central peak of the solvent signal. Cp refers to the unsubstituted cyclopentadienyl ring on ferrocene. Optical rotations were recorded at $20^{\circ} \mathrm{C}$ on a Perkin Elmer 341 polarimeter. Enantiomeric ratios (er) were determined by chiral HPLC on a ThermoFischer Ultimate 3000 apparatus. $\mathrm{ZnCl}_{2}$ was recrystallized from dioxane in the presence of zinc dust and dried under high vacuum at $150{ }^{\circ} \mathrm{C}$ overnight. (+)-Sparteine surrogate was prepared according to $\mathrm{O}^{\prime}$ Brien and was distilled over $\mathrm{CaH}_{2}$ before use. ${ }^{16}$ Piperic acid was prepared according to Singh. ${ }^{23}$

Safety Considerations. Due to its high pyrophoric character, $t$ BuLi needs to be used only under inert conditions (anhydrous, nitrogen or argon atmosphere) and by people well trained to the manipulation of reactive organometallics. Due to the inherent dangers of using cryogenic temperatures, experiments should be performed by well-trained people.

\section{Procedures}

\section{Ferrocenecarboxylic acid (3)}

[CAS Reg. No. 1271-42-7]

Ferrocene $(29.8 \mathrm{~g}, 160 \mathrm{mmol}, 1.00$ equiv) and $t \mathrm{BuOK}(1.79 \mathrm{~g}, 16.0 \mathrm{mmol}$, 0.100 equiv) were introduced into a $2 \mathrm{~L}$ flame-dried round-bottom flask which was then subjected to three cycles of vacuum/argon. Anhydrous THF (1.23 L) was introduced by cannula and the reaction mixture was stirred at rt until dissolution of all solids. The reaction mixture was cooled between -85 and $-80{ }^{\circ} \mathrm{C}$ (external temperature) in an acetone/liquid nitrogen bath. $t$ BuLi $(1.6 \mathrm{M}, 320 \mathrm{mmol}, 200 \mathrm{~mL}, 2.00$ equiv) was then introduced dropwise by cannula keeping the temperature of the bath between -85 and $-80^{\circ} \mathrm{C}$. After addition, the reaction mixture was stirred at the same temperature for $1 \mathrm{~h}$. Gaseous $\mathrm{CO}_{2}$ (dried by bubbling through concentrated $\mathrm{H}_{2} \mathrm{SO}_{4}$ and passing through an anhydrous $\mathrm{CaCl}_{2}$ column) was bubbled into the reaction mixture for $30 \mathrm{~min}$, keeping the temperature of the bath between -85 and $-80^{\circ} \mathrm{C}$. The reaction mixture was then allowed to warm to $-15^{\circ} \mathrm{C}$, keeping the flask into the bath, with a continued bubbling of $\mathrm{CO}_{2}$. At $-15^{\circ} \mathrm{C}$, bubbling of $\mathrm{CO}_{2}$ was stopped, the cooling bath was removed and the reaction mixture was warmed to rt. Water $(200 \mathrm{~mL})$ was slowly added to the reaction mixture which was then extracted with $10 \% \mathrm{NaOH}(6 \times 150 \mathrm{~mL})$. The combined aqueous layers were backwashed with $\mathrm{Et}_{2} \mathrm{O}(4 \times 250 \mathrm{~mL})$, cooled to $0^{\circ} \mathrm{C}$ (ice-water bath) and acidified with $\mathrm{HCl}(35 \%)$ until $\mathrm{pH} 1$ was reached. Caution: vigorous evolution of $\mathrm{CO}_{2}$ occurred upon acidification. The resulting solids were filtered on a sintered-glass funnel (porosity 3), washed with water $(5 \times 250 \mathrm{~mL})$ and pentane $(1 \times 250 \mathrm{~mL})$, wringing the solid under vacuum between each wash. The resulting solid was dried overnight under high-vacuum $(2$ mbar) using $\mathrm{P}_{2} \mathrm{O}_{5}$ trap to give the title product as an orange solid (34.6 g, 94\%). $\mathrm{Rf}$ (PET-EtOAc 75:25) $=0.30 . \mathrm{Mp} 208-210^{\circ} \mathrm{C}$ (decomp.). Analytical data analogous to those reported previously. ${ }^{24}$

$v_{\max }\left(\right.$ film) $/ \mathrm{cm}^{-1} 2882$ (br), 1651, 1474, 1282, 1158, 1029, 936, 914, 834, 740 .

${ }^{1} \mathrm{H}$ NMR (500 MHz, DMSO-d $)$ : $\delta(\mathrm{ppm}) 12.15$ (br s, $\left.1 \mathrm{H}, \mathrm{CO}_{2} \mathrm{H}\right), 4.69(\mathrm{~s}, 2 \mathrm{H}$, $2 \times \mathrm{FcCH}), 4.43$ (s, $2 \mathrm{H}, 2 \times \mathrm{FcCH}), 4.21$ (s, 5H, Cp).

${ }^{13} \mathrm{C}$ NMR (126 MHz, DMSO-d 6 ): $\delta(\mathrm{ppm}) 172.1\left(\mathrm{CO}_{2} \mathrm{H}\right), 71.8(\mathrm{FcC}), 71.0(2$ $\mathrm{x} \mathrm{FcCH}), 69.9(2 \mathrm{x} \mathrm{FCCH}), 69.5$ (Cp).

\section{N,N-Diisopropylferrocenecarboxamide (1)}

\section{[CAS Reg. No. 169830-46-0]}

Compound 3 (27.6 g, $120 \mathrm{mmol}, 1.00$ equiv) was introduced into a $1 \mathrm{~L}$ round-bottom flask equipped with a bubbler and an addition funnel. $\mathrm{CH}_{2} \mathrm{Cl}_{2}$ (undried standard quality, $480 \mathrm{~mL}$ ) and dimethylformamide (undried standard quality, $0.50 \mathrm{~mL}, 425 \mathrm{mg}, 5.80 \mathrm{mmol}, 50.0$ equiv) were introduced and the resulting orange suspension was stirred at rt. Oxalyl chloride ( $25.4 \mathrm{~mL}, 38.1 \mathrm{~g}, 300 \mathrm{mmol}, 2.50$ equiv) was added dropwise over 20 min. Caution: evolution of $\mathrm{CO}$ and $\mathrm{CO}_{2}$ required to work under a wellventilated fume hood. After addition, the addition funnel was washed with $\mathrm{CH}_{2} \mathrm{Cl}_{2}(10.0 \mathrm{~mL})$ and the reaction mixture was then stirred at $\mathrm{rt}$ for 30 min. Remark: as the reaction proceeds, the orange solid slowly dissolves leading to a dark-red solution of $\mathrm{FcCOCl}$. All volatiles were removed under vacuum using a rotary evaporator and the resulting oil was kept under high vacuum ( 2 mbar) for 5 min before being dissolved in $\mathrm{CH}_{2} \mathrm{Cl}_{2}$ (undried standard quality, $480 \mathrm{~mL}$ ). Diisopropylamine (50.5 mL, $36.4 \mathrm{~g}, 360 \mathrm{mmol}$, 
3.00 equiv) was added dropwise over $30 \mathrm{~min}$. Caution: a slightly exothermic reaction was noticed, however not high enough for solvent boiling. After addition, the reaction mixture was stirred for an additional $30 \mathrm{~min}$ at $\mathrm{rt}$. All volatiles were removed under vacuum using a rotary evaporator and the resulting oil was kept under high vacuum ( 2 mbar) for 5 min. $\mathrm{Et}_{2} \mathrm{O}(500 \mathrm{~mL})$ was added and the reaction mixture was washed with $\mathrm{HCl}(1.0 \mathrm{M}$ aq., $150 \mathrm{~mL})$. Remark: in case of emulsion formation, filtration over cotton wool can be done. The aqueous layer was backwashed with $\mathrm{Et}_{2} \mathrm{O}(100 \mathrm{~mL})$. The combined organic layers were washed with $\mathrm{NaOH}(5 \%, 150 \mathrm{~mL})$, water $(150 \mathrm{~mL})$, brine $(150 \mathrm{~mL})$, dried over $\mathrm{MgSO}_{4}$, filtered over a pad of Celite $(\varnothing 6, \mathrm{~h} 4 \mathrm{~cm}$, sintered glass funnel porosity 3) and concentrated under vacuum to give the crude product. The residue was transferred into a $250 \mathrm{~mL}$ round-bottom flask using heptane $(65 \mathrm{~mL})$. The solution was heated at reflux, allowed to cool to rt and then kept at $-20{ }^{\circ} \mathrm{C}$ overnight. Using a cannula, the solution was pumped off from the solid which was washed with cooled pentane $\left(-30^{\circ} \mathrm{C}\right.$ $1 \times 15 \mathrm{~mL}$ ). The resulting solid was dried under high-vacuum ( 2 mbar) to give the title product as an orange solid (35.9 g, 95.5\%). $\mathrm{R}_{\mathrm{f}}$ (eluent: PET EtOAc $75: 25)=0.65 . \mathrm{Mp} 73-75^{\circ} \mathrm{C}$. Analytical data analogous to those reported previously. ${ }^{13}$

$v_{\max }($ film $) / \mathrm{cm}^{-1} 3084,2972,1627,1463,1423,1369,1317,1200,1151$, $1135,1105,1041,1025,823,806$

${ }^{1} \mathrm{H}$ NMR (500 MHz, $\left.\mathrm{CDCl}_{3}\right): \delta(\mathrm{ppm}) 4.58(\mathrm{br} \mathrm{s}, 1 \mathrm{H}, \mathrm{CH}), 4.52(\mathrm{t}, J=1.7 \mathrm{~Hz}$ $2 \mathrm{H}, 2 \times \mathrm{FcCH}$ ), $4.22(\mathrm{t}, J=1.7 \mathrm{~Hz}, 2 \mathrm{H}, 2 \times \mathrm{FcCH}$ ), 4.19 (s, 5H, Cp), 3.38 (br s, $1 \mathrm{H}, \mathrm{CH}$ ), 1.44 (br s, 6H, $2 \times \mathrm{CH}_{3}$ ), 1.18 (br s, $6 \mathrm{H}, 2 \times \mathrm{CH}_{3}$ ).

${ }^{13} \mathrm{C}$ NMR (126 MHz, $\mathrm{CDCl}_{3}$ ): $\delta(\mathrm{ppm}) 169.5(\mathrm{C}=0), 81.4(\mathrm{FcC}), 70.1(2 \mathrm{x}$ $\mathrm{FcCH}), 69.8$ (Cp), 68.9 (2 x FcCH), $49.6(\mathrm{CH}), 46.4(\mathrm{CH}), 21.3\left(4 \times \mathrm{CH}_{3}\right)$

Mass: 313 [M], 213 [M-NiPr2]

\section{( $)$-2-iodo- $N, N$-diisopropylferrocenecarboxamide (( \pm$)-2)$ by using} nBuLi-TMEDA

\section{[CAS Reg. No. 344927-04-4]}

TMEDA (21.0 mL, $16.3 \mathrm{~g}, 140 \mathrm{mmol}, 1.50$ equiv, freshly distilled over $\mathrm{CaCl}_{2}$ and stored over $\mathrm{KOH}$ pellets) and anhydrous $\mathrm{Et}_{2} \mathrm{O}(430.0 \mathrm{~mL})$ were introduced into a $2 \mathrm{~L}$ flame-dried round-bottom flask under argon. The reaction mixture was cooled to between -85 and $-80{ }^{\circ} \mathrm{C}$ (external temperature) in an acetone/liquid nitrogen bath. $n \mathrm{BuLi}(1.4 \mathrm{M}, 100 \mathrm{~mL}$ $140 \mathrm{mmol}, 1.50$ equiv) was then introduced dropwise by cannula, keeping the temperature of the bath between -85 and $-80^{\circ} \mathrm{C}$. After addition, the reaction mixture was stirred at the same temperature for $15 \mathrm{~min}$ Compound 2 (29.2 g, $93.3 \mathrm{mmol}, 1.00$ equiv) was introduced into a separate $1 \mathrm{~L}$ flame-dried round-bottom flask which was subjected to three cycles of vacuum/argon. Anhydrous $\mathrm{Et}_{2} \mathrm{O}(430 \mathrm{~mL})$ was added and the solution was stirred until dissolution of all solids. The solution of $\mathbf{1}$ was transferred into the $n$ BuLi-TMEDA solution dropwise by cannula, keeping the temperature of the bath between -85 and $-80^{\circ} \mathrm{C}$. The flask was washed with $10.0 \mathrm{~mL}$ of anhydrous $\mathrm{Et}_{2} \mathrm{O}$, also transferred by cannula. After addition, the reaction mixture was stirred at the same temperature for 1 h. Iodine ( $47.4 \mathrm{~g}, 187 \mathrm{mmol}, 2.00$ equiv) was introduced in a separate $1 \mathrm{~L}$ flame-dried round-bottom flask under argon and was dissolved into anhydrous $\mathrm{Et}_{2} \mathrm{O}(800 \mathrm{~mL})$. The iodine solution was transferred to the lithioferrocene solution dropwise by cannula, keeping the temperature of the bath between -85 and $-80{ }^{\circ} \mathrm{C}$. The flask was washed with $10.0 \mathrm{~mL}$ of anhydrous $\mathrm{Et}_{2} \mathrm{O}$, also transferred by cannula. The reaction mixture was then allowed to warm to $-15{ }^{\circ} \mathrm{C}$, keeping the flask into the bath. At $-15{ }^{\circ} \mathrm{C}$ the cooling bath was removed and the reaction mixture was warmed to rt. Remark: at this stage, the reaction mixture can be kept at $-20^{\circ} \mathrm{C}$ overnight before work-up if required. Half of the solvent was removed under vacuum and EtOAc $(800 \mathrm{~mL})$ was added. The reaction mixture was washed with $\mathrm{Na}_{2} \mathrm{~S}_{2} \mathrm{O}_{3}$ (sat. aq., $2 \times 150 \mathrm{~mL}$ ), water $(2 \times 150 \mathrm{~mL})$, brine ( 1 x $150 \mathrm{~mL}$ ), dried over $\mathrm{MgSO}_{4}$, filtered over cotton wool and concentrated under vacuum using a rotary evaporator. The resulting oil was dissolved in hot heptane/EtOAc $(80: 20)$ solution and was hot filtered over a pad of silica ( $\varnothing 6, \mathrm{~h} 4 \mathrm{~cm}$, sintered glass funnel porosity 3 ), which was washed with the same hot solvent until the filtrate was colourless. The filtrate was then concentrated under vacuum using a rotary evaporator to give the crude product. This was dissolved into heptane $(100 \mathrm{~mL})$, the solution was heated at reflux, allowed to cool to rt and then kept at $-20{ }^{\circ} \mathrm{C}$ overnight. Using a cannula, the solution was pumped off from the solid which was washed with cooled pentane $\left(-30^{\circ} \mathrm{C}, 2 \times 40 \mathrm{~mL}\right)$. The solution was pumped off using a cannula. The resulting solid was dried under high-vacuum (2 mbar) to give the title product as an orange solid $(35.9 \mathrm{~g}, 88 \%) . \mathrm{R}_{\mathrm{f}}$ (eluent: PET-EtOAc 80:20) $=0.68$. Mp 137-139 ${ }^{\circ} \mathrm{C}$. Analytical data analogous to those reported previously. ${ }^{13}$

$\nu_{\max }($ film $) / \mathrm{cm}^{-1} 2971,1619,1456,1368,1315,1298,1206,1036,811$, 686.

${ }^{1} \mathrm{H}$ NMR (500 MHz, CDCl $): \delta(\mathrm{ppm}) 4.36$ (q, J=1.7, $\left.1.1 \mathrm{~Hz}, 1 \mathrm{H}, \mathrm{FcCH}\right), 4.28$ (s, 5H, Cp), 4.22 (q, J = 2.0, 1.1 Hz, 1H, FcCH), 4.11 (t, J=2.4 Hz, 1H, FcCH), $3.55(\mathrm{t}, J=5.5 \mathrm{~Hz}, 1 \mathrm{H}, \mathrm{CH}), 3.33(\mathrm{t}, J=5.5 \mathrm{~Hz}, 1 \mathrm{H}, \mathrm{CH}), 1.45\left(\mathrm{~s}, 6 \mathrm{H}, 2 \times \mathrm{CH}_{3}\right)$, $1.03\left(\mathrm{~d}, J=5.5 \mathrm{~Hz}, 3 \mathrm{H}, \mathrm{CH}_{3}\right), 0.92\left(\mathrm{~d}, J=5.5 \mathrm{~Hz}, 3 \mathrm{H}, \mathrm{CH}_{3}\right)$.

${ }^{13} \mathrm{C} \mathrm{NMR}\left(126 \mathrm{MHz}, \mathrm{CDCl}_{3}\right): \delta(\mathrm{ppm}) 166.3(\mathrm{C}=0), 92.6(\mathrm{FcC}), 73.6(\mathrm{FcCH})$, $72.7(\mathrm{Cp}), 67.6(\mathrm{FcCH}), 66.8(\mathrm{FcCH}), 50.8(\mathrm{CH}), 45.9(\mathrm{CH}), 40.5(\mathrm{FcC}-\mathrm{I}), 21.0$ $\left(2 \times \mathrm{CH}_{3}\right), 20.8\left(\mathrm{CH}_{3}\right), 20.7\left(\mathrm{CH}_{3}\right)$.

Mass: 439 [M], 311 [M-CONiPr2], 268.

\section{$( \pm)$-2-iodo- $N, N$-diisopropylferrocenecarboxamide (( \pm$)$-2) by using LiTMP-ZnCl 2}

[CAS Reg. No. 344927-04-4]

$n$ BuLi (1.4 M, $71.4 \mathrm{~mL}, 100 \mathrm{mmol}, 2.00$ equiv) was added dropwise by cannula to a solution of TMPH (16.9 mL, $14.1 \mathrm{~g}, 100 \mathrm{mmol}, 2.00$ equiv) in $\mathrm{THF}(80.0 \mathrm{~mL})$ at $-20^{\circ} \mathrm{C}$. After addition, the reaction mixture was stirred at the same temperature for $10 \mathrm{~min}$. The reaction mixture was cooled to $30{ }^{\circ} \mathrm{C}$ and was cannulated onto a solution of compound 1 (15.7 g, 50.0 mmol, 1.00 equiv) and $\mathrm{ZnCl}_{2}(6.81 \mathrm{~g}, 50.0 \mathrm{mmol}, 1.00$ equiv) in THF (100 $\mathrm{mL}$ ) at $-30{ }^{\circ} \mathrm{C}$. The LiTMP flask was washed with THF $(10 \mathrm{~mL})$. The reaction mixture was warmed to $-10^{\circ} \mathrm{C}$ over $2 \mathrm{~h}$ and a solution of iodine ( $25.4 \mathrm{~g}, 100 \mathrm{mmol}, 2.00$ equiv) in THF $(130 \mathrm{~mL})$ was added by cannula. The iodine flask was washed with THF $(10 \mathrm{~mL})$. The cooling bath was removed and the reaction mixture was warmed to $\mathrm{rt}$. Half of the solvent was removed under vacuum and EtOAc $(430 \mathrm{~mL})$ was added. By following a similar work-up procedure as the one described before, adjusting the quantities, the title product was obtained as an orange solid $(20.5 \mathrm{~g}, 93 \%)$. Analytical data analogous to those reported above.

\section{$\left(S_{p}\right)$-2-iodo- $N, N$-diisopropylferrocenecarboxamide $\left(\left(S_{p}\right)-2\right)$}

(+)-Sparteine surrogate (1.16 g, $6.00 \mathrm{mmol}, 1.30$ equiv) and anhydrous $\mathrm{Et}_{2} \mathrm{O}(70.0 \mathrm{~mL})$ were introduced into a $250 \mathrm{~mL}$ flame-dried round-bottom flask under argon. The reaction mixture was cooled to between -85 and $80{ }^{\circ} \mathrm{C}$ (external temperature) in an acetone/liquid nitrogen bath. $n \mathrm{BuLi}$ (1.4 M, $4.30 \mathrm{~mL}, 6.00 \mathrm{mmol}, 1.30$ equiv) was then introduced dropwise by syringe, keeping the temperature of the bath between -85 and $-80^{\circ} \mathrm{C}$. After addition, the reaction mixture was stirred at the same temperature for 30 min. Compound 1 ( $1.40 \mathrm{~g}, 4.50 \mathrm{mmol}, 1.00$ equiv) was introduced into a separate $20 \mathrm{~mL}$ flame-dried round-bottom flask which was subjected to three cycles of vacuum/argon. Anhydrous toluene $(10.0 \mathrm{~mL})$ was added and the solution was stirred until dissolution of all solids had occurred. The solution of 1 was transferred into the $n \mathrm{BuLi} /(+)$-Sparteine surrogate solution dropwise by cannula, keeping the temperature of the bath between -85 and $-80{ }^{\circ} \mathrm{C}$. The flask was washed with $2.0 \mathrm{~mL}$ of anhydrous $\mathrm{Et}_{2} \mathrm{O}$, also transferred by cannula. After addition, the reaction mixture was stirred at the same temperature for $2 \mathrm{~h}$. Iodine $(2.30 \mathrm{~g}, 9.00 \mathrm{mmol}, 2.00$ equiv) was introduced into a separate $100 \mathrm{~mL}$ flame-dried round-bottom flask under argon and was dissolved into anhydrous $\mathrm{Et}_{2} \mathrm{O}(60.0 \mathrm{~mL})$. The iodine solution was transferred to the lithioferrocene solution dropwise by cannula, keeping the temperature of the bath between -85 and $-80{ }^{\circ} \mathrm{C}$. The flask was washed with $5.0 \mathrm{~mL}$ of anhydrous $\mathrm{Et}_{2} \mathrm{O}$, also transferred by cannula. The reaction mixture was then allowed to warm to $-15{ }^{\circ} \mathrm{C}$, keeping the flask into the bath. At $-15^{\circ} \mathrm{C}$, the cooling bath was removed and the reaction mixture was warmed to rt. $\mathrm{Na}_{2} \mathrm{~S}_{2} \mathrm{O}_{3}$ (sat. aq., $100 \mathrm{~mL}$ ), EtOAc $(100 \mathrm{~mL})$ and water $(50 \mathrm{~mL})$ were added to the reaction mixture, layers were separated and the aqueous one was backwashed with EtOAc $(50 \mathrm{~mL})$. The organic layer was washed with $\mathrm{H}_{3} \mathrm{PO}_{4}(5 \%$ aq., $3 \times 30 \mathrm{~mL})$ and the combined aqueous layers were backwashed with EtOAc $(50 \mathrm{~mL})$. The combined organic layers were washed with water $(2 \times 50 \mathrm{~mL})$, brine (1 x $50 \mathrm{~mL}$ ), dried over $\mathrm{MgSO}_{4}$, filtered over cotton wool and concentrated under vacuum using a rotary evaporator to give the crude product. This was purified by column chromatography over $\mathrm{SiO}_{2}$, using PET-EtOAc (10:1 to 9:1) to give the title product as an orange oil $(1.4 \mathrm{~g}, 69 \%, 96: 4 \mathrm{er})$. Analytical data analogous to racemic compound. $[\alpha]_{\mathrm{D}}-87.9$ (c 0.01 in $\mathrm{CHCl}_{3}$ ). The enantiomeric ratio was determined on Chiralpak IC-3 column, hexane-iPrOH: $98: 2,1.5 \mathrm{~mL} / \mathrm{min}, 20^{\circ} \mathrm{C}, \lambda=254 \mathrm{~nm}, \mathrm{t}$ (major) $=10.19 \mathrm{~min}$, $\mathrm{t}$ (minor) $=7.64 \mathrm{~min}$ ). Recrystallization from hot heptane as described for the racemic product increased the er to $99: 1$ as determined by chiral HPLC. CCDC 1898624.

\section{General procedure A: Suzuki-Miyaura cross-coupling of ( \pm )-2}

Compound ( \pm )-2 (242 mg, 0.55 mmol, 1.00 equiv), arylboronic acid (2.20 mmol, 4.00 equiv), Pd(dba) 2 (15.8 mg, $27.5 \mu \mathrm{mol}, 5 \mathrm{~mol} \%), \mathrm{CsF}(167 \mathrm{mg}$, 1.10 mmol, 2.00 equiv) and $\mathrm{PPh}_{3}(28.5 \mathrm{mg}, 0.11 \mathrm{mmol}, 0.20$ equiv) were placed in a dried Schlenk tube, subjected to three cycles of vacuum/argon. Toluene $(5.00 \mathrm{~mL})$ was added and the reaction mixture was stirred overnight at $120{ }^{\circ} \mathrm{C}$ (external temperature) in a pre-heated oil bath. The reaction mixture was cooled to $\mathrm{rt}$, water $(10 \mathrm{~mL})$ was added and the reaction mixture was extracted with EtOAc $(2 \times 10 \mathrm{~mL})$. The combined organic layers were dried over $\mathrm{MgSO}_{4}$, filtered over cotton wool and 
concentrated under vacuum using a rotary evaporator to give the crude product. This was purified by column chromatography over $\mathrm{SiO}_{2}$, using PET-EtOAc (proportions given for each product) to give the title product.

\section{$( \pm)$ - $N, N$-Diisopropyl-2-phenylferrocenecarboxamide ( $( \pm)-4)$}

By following the general procedure A, using phenylboronic acid (268 mg) ( \pm )-4 was obtained after column chromatography (PET-EtOAc, 90:10) as an orange solid (125 mg, 58.5\%). $\mathrm{R}_{\mathrm{f}}$ (eluent: PET-EtOAc 90:10) $=0.54$. Mp $134-136^{\circ} \mathrm{C}$. CCDC 1909912.

$v_{\max }($ film $) / \mathrm{cm}^{-1} 2965,1626,1463,1442,1343,1317,1304,1215,1136$, $1105,1035,818,765,698$.

${ }^{1} \mathrm{H}$ NMR (500 MHz, CDCl $): \delta(\mathrm{ppm}) 7.52(\mathrm{~d}, J=8.0 \mathrm{~Hz}, 2 \mathrm{H}, 2 \times \mathrm{ArCH}), 8.23$ (m, 2H, $2 \times \mathrm{ArCH}), 7.17$ (d, $J=7.1 \mathrm{~Hz}, 1 \mathrm{H}, \mathrm{ArCH}), 4.45(\mathrm{dd}, J=1.4,2.0 \mathrm{~Hz}$, $1 \mathrm{H}, \mathrm{FcCH}), 4.41$ (dd, $J=1.4,2.0 \mathrm{~Hz}, 1 \mathrm{H}, \mathrm{FcCH}), 4.24-4.23(\mathrm{~m}, 6 \mathrm{H}, \mathrm{Cp}+\mathrm{FcCH})$ 3.47 (sept, $J=6.7 \mathrm{~Hz}, 1 \mathrm{H}, \mathrm{CH}$ ), 3.19 (sept, $J=6.8 \mathrm{~Hz}, 1 \mathrm{H}, \mathrm{CH}$ ), 1.47 (d, $J=6.8$ $\left.\mathrm{Hz}, 3 \mathrm{H}, \mathrm{CH}_{3}\right), 1.38\left(\mathrm{~d}, J=6.8 \mathrm{~Hz}, 3 \mathrm{H}, \mathrm{CH}_{3}\right), 0.81\left(\mathrm{~d}, J=6.7 \mathrm{~Hz}, 3 \mathrm{H}, \mathrm{CH}_{3}\right), 0.24$ $\left(\mathrm{d}, J=6.7 \mathrm{~Hz}, 3 \mathrm{H}, \mathrm{CH}_{3}\right)$.

${ }^{13} \mathrm{C} \mathrm{NMR}\left(126 \mathrm{MHz}, \mathrm{CDCl}_{3}\right.$ ): $\delta(\mathrm{ppm}) 168.2$ (C=0), $138.3(\mathrm{ArC}), 128.3(2 \mathrm{x}$ $\mathrm{ArCH}), 128.2$ (2 x ArCH), 126.7 ( $\mathrm{ArCH}), 90.1$ (FcC-CO), 84.9 (FcC), 71.4 (Cp), $69.8(\mathrm{FcCH}), 67.0(\mathrm{FcCH}), 64.9(\mathrm{FcCH}), 50.8(\mathrm{CH}), 45.9(\mathrm{CH}), 21.4$ $\left(\mathrm{CH}_{3}\right), 21.1\left(\mathrm{CH}_{3}\right), 19.9\left(\mathrm{CH}_{3}\right), 19.5\left(\mathrm{CH}_{3}\right)$.

Mass: 389 [M], 289 [M-NiPr 2$].$

\section{( \pm )- $N, N$-Diisopropyl-2-(4-methoxyphenyl)ferrocenecarboxamide} (( \pm )-5)

By following the general procedure A, using 4-methoxyphenylboronic acid (334 mg), ( $\mathbf{+}$ )-5 was obtained after column chromatography (PET EtOAc, 10:1) as an orange solid (197 mg, 77\%). Rf (eluent: PET-EtOAc $80: 20)=0.57 . \mathrm{Mp} 142-144^{\circ} \mathrm{C}$. CCDC 1909910.

$\nu_{\max }\left(\right.$ film) $/ \mathrm{cm}^{-1} 2962,2931,1625,1460,1437,1341,1314,1305,1289$, $1243,1106,1027,906,845,815,734$.

${ }^{1} \mathrm{H}$ NMR (500 MHz, $\left.\mathrm{CDCl}_{3}\right): \delta(\mathrm{ppm}) 7.45(\mathrm{~d}, J=8.8 \mathrm{~Hz}, 2 \mathrm{H}, 2 \times \mathrm{ArCH}), 6.79$ (d, $J=8.8 \mathrm{~Hz}, 2 \mathrm{H}, 2 \times \mathrm{ArCH}$ ), 4.41 (dd, $J=1.5,2.2 \mathrm{~Hz}, 1 \mathrm{H}, \mathrm{FcCH}$ ), 4.38 (dd, $J$ $=1.5,2.2 \mathrm{~Hz}, 1 \mathrm{H}, \mathrm{FcCH}), 4.23(\mathrm{~s}, 5 \mathrm{H}, \mathrm{Cp}), 4.20(\mathrm{t}, J=2.2 \mathrm{~Hz}, 1 \mathrm{H}, \mathrm{FcCH}), 3.78$ $\left(\mathrm{s}, 3 \mathrm{H}, \mathrm{OCH}_{3}\right.$ ), 3.48 (sept, $J=6.7 \mathrm{~Hz}, 1 \mathrm{H}, \mathrm{CH}$ ), 3.20 (sept, $J=6.7 \mathrm{~Hz}, 1 \mathrm{H}, \mathrm{CH}$ ) $1.48\left(\mathrm{~d}, J=6.7 \mathrm{~Hz}, 3 \mathrm{H}, \mathrm{CH}_{3}\right), 1.38\left(\mathrm{~d}, J=6.7 \mathrm{~Hz}, 3 \mathrm{H}, \mathrm{CH}_{3}\right), 0.83(\mathrm{~d}, J=6.7 \mathrm{~Hz}$ $\left.3 \mathrm{H}, \mathrm{CH}_{3}\right), 0.30\left(\mathrm{~d}, J=6.7 \mathrm{~Hz}, 3 \mathrm{H}, \mathrm{CH}_{3}\right)$.

${ }^{13} \mathrm{C}$ NMR (126 MHz, $\mathrm{CDCl}_{3}$ ): $\delta$ (ppm) 168.3 (C=0), 158.6 (ArC-0), 130.4 (ArC), 129.3 ( $2 \times \mathrm{ArCH}), 113.7$ ( $2 \times \mathrm{ArCH}), 89.3$ (FcC-CO), 85.1 (FcC), 71.3 (Cp), $69.4(\mathrm{FcCH}), 66.6(\mathrm{FcCH}), 64.9(\mathrm{FcCH}), 55.4\left(\mathrm{OCH}_{3}\right), 50.8(\mathrm{CH}), 45.8$ (CH), $21.3\left(\mathrm{CH}_{3}\right), 21.0\left(\mathrm{CH}_{3}\right), 19.9\left(\mathrm{CH}_{3}\right), 19.7\left(\mathrm{CH}_{3}\right)$.

Mass: 491 [M], 319 [M-NiPr2].

(士)- $N, N$-Diisopropyl-2-(2,4-dimethoxyphenyl)ferrocenecarboxamide (( \pm$)-6)$

[CAS Reg. No. 173911-02-9]

By following the general procedure A, using 2,4-dimethoxyphenylboronic acid (400 mg), ( \pm ) -6 was obtained after column chromatography (PETEtOAc, 10:1) as an orange solid (174 mg, 64\%). R (eluent: PET-EtOAc $80: 20)=0.59 . \mathrm{Mp} 163-166^{\circ} \mathrm{C}$. Analytical data analogous to those reported previously. ${ }^{7}$ CCDC 1909911.

$v_{\max }\left(\right.$ film) $/ \mathrm{cm}^{-1} 2964,1625,1505,1450,1341,1310,122,1037,1104$ $809,735$.

${ }^{1} \mathrm{H}$ NMR (500 MHz, $\left.\mathrm{CDCl}_{3}\right): \delta(\mathrm{ppm}) 7.43(\mathrm{~d}, J=2.6 \mathrm{~Hz}, 1 \mathrm{H}, \mathrm{ArCH}), 6.75-$ $6.70(\mathrm{~m}, 2 \mathrm{H}, 2 \times \mathrm{ArCH}), 4.63(\mathrm{dd}, J=1.5,2.3 \mathrm{~Hz}, 1 \mathrm{H}, \mathrm{FcCH}), 4.41$ (dd, $J=1.5$ $2.2 \mathrm{~Hz}, 1 \mathrm{H}, \mathrm{FcCH}), 4.26(\mathrm{~s}, 5 \mathrm{H}, \mathrm{Cp}), 4.25(\mathrm{t}, J=2.2 \mathrm{~Hz}, 1 \mathrm{H}, \mathrm{FcCH}), 3.79(\mathrm{~s}$, $3 \mathrm{H}, \mathrm{OCH}_{3}$ ), $3.71\left(\mathrm{~s}, 3 \mathrm{H}, \mathrm{OCH}_{3}\right.$ ), 3.53 (sept, $J=6.7 \mathrm{~Hz}, 1 \mathrm{H}, \mathrm{CH}$ ), 3.16 (sept, $J$ $=6.7 \mathrm{~Hz}, 1 \mathrm{H}, \mathrm{CH}), 1.45\left(\mathrm{~d}, J=6.7 \mathrm{~Hz}, 3 \mathrm{H}, \mathrm{CH}_{3}\right), 1.32\left(\mathrm{~d}, J=6.7 \mathrm{~Hz}, 3 \mathrm{H}, \mathrm{CH}_{3}\right)$, $0.82\left(\mathrm{~d}, J=6.7 \mathrm{~Hz}, 3 \mathrm{H}, \mathrm{CH}_{3}\right), 0.28\left(\mathrm{~d}, J=6.7 \mathrm{~Hz}, 3 \mathrm{H}, \mathrm{CH}_{3}\right)$.

${ }^{13} \mathrm{C}$ NMR (126 MHz, $\mathrm{CDCl}_{3}$ ): $\delta$ (ppm) $168.2(\mathrm{C}=0), 153.3$ (ArC-0), 151.5 (ArC-0), 127.1 (ArC), 117.4 (ArCH), 113.5 (ArCH), $112.1(\mathrm{ArCH}), 90.8$ (FcC-CO), 81.5 (FcC), $71.3(\mathrm{Cp}), 69.0(\mathrm{FcCH}), 68.7(\mathrm{FcCH}), 66.7(\mathrm{FcCH})$ $56.1\left(\mathrm{OCH}_{3}\right), 55.8\left(\mathrm{OCH}_{3}\right), 50.6(\mathrm{CH}), 45.7(\mathrm{CH}), 21.2\left(\mathrm{CH}_{3}\right), 21.1\left(\mathrm{CH}_{3}\right), 20.3$ $\left(\mathrm{CH}_{3}\right), 19.7\left(\mathrm{CH}_{3}\right)$

Mass: 449 [M], 349 [M-NiPr2].

( \pm )- $N, N$-Diisopropyl-2-(2-naphthyl)ferrocenecarboxamide (( \pm$)-7)$

By following the general procedure A, using 2-naphthylboronic acid (378 $\mathrm{mg}$ ), ( \pm )-7 was obtained after column chromatography (PET-EtOAc, 90:10) as an orange solid (156 mg, 64.5\%). Rf (eluent: PET-EtOAc 90:10) $=0.43 . \mathrm{Mp} 218-220^{\circ} \mathrm{C}$. CCDC 1909914.

$v_{\max }($ film $) / \mathrm{cm}^{-1} 2966,1622,1462,1334,1303,1201,1134,1040,864$, $820,808,755$.
${ }^{1} \mathrm{H}$ NMR $\left(500 \mathrm{MHz}^{\mathrm{CDCl}} 3\right): \delta(\mathrm{ppm}) 7.94(\mathrm{~s}, 1 \mathrm{H}, \mathrm{ArCH}), 7.78-7.74(\mathrm{~m}, 2 \mathrm{H}, 2$ $\mathrm{x} \mathrm{ArCH}), 7.74(\mathrm{~m}, 2 \mathrm{H}, 2 \times \mathrm{ArCH}), 7.45-7.40(\mathrm{~m}, 2 \mathrm{H}, 2 \times \mathrm{ArCH}), 4.61(\mathrm{dd}, J=$ 1.5, $2.3 \mathrm{~Hz}, 1 \mathrm{H}, \mathrm{FcCH}$ ), 4.49 (dd, $J=1.4,2.3 \mathrm{~Hz}, 1 \mathrm{H}, \mathrm{FcCH}), 4.32(\mathrm{t}, J=2.3$ $\mathrm{Hz}, 1 \mathrm{H}, \mathrm{FcCH}$ ), 3.55 (sept, $J=6.7 \mathrm{~Hz}, 1 \mathrm{H}, \mathrm{CH}$ ), 3.20 (sept, $J=6.8 \mathrm{~Hz}, 1 \mathrm{H}, \mathrm{CH}$ ), $1.52\left(\mathrm{~d}, J=6.8 \mathrm{~Hz}, 3 \mathrm{H}, \mathrm{CH}_{3}\right), 1.43\left(\mathrm{~d}, J=6.8 \mathrm{~Hz}, 3 \mathrm{H}, \mathrm{CH}_{3}\right), 0.84(\mathrm{~d}, J=6.7 \mathrm{~Hz}$, $\left.3 \mathrm{H}, \mathrm{CH}_{3}\right), 0.19\left(\mathrm{~d}, J=6.7 \mathrm{~Hz}, 3 \mathrm{H}, \mathrm{CH}_{3}\right)$.

${ }^{13} \mathrm{C}$ NMR (126 MHz, CDCl $)$ : $\delta(\mathrm{ppm}) 168.3(\mathrm{C}=0), 136.1(\mathrm{ArC}), 133.6(\mathrm{ArC})$ 132.5 (ArC), $127.9(\mathrm{ArCH}), 127.8(\mathrm{ArCH}), 127.7(\mathrm{ArCH}), 127.1(\mathrm{ArCH})$ 126.4 (ArCH), $125.8(\mathrm{ArCH}), 125.6(\mathrm{ArCH}), 90.3$ (FcC-CO), 84.5 (FcC), 71.5 (Cp), $70.2(\mathrm{FcCH}), 67.3(\mathrm{FcCH}), 65.0(\mathrm{FcCH}), 50.9(\mathrm{CH}), 45.9(\mathrm{CH}), 21.4$ $\left(\mathrm{CH}_{3}\right), 21.1\left(\mathrm{CH}_{3}\right), 20.0\left(\mathrm{CH}_{3}\right), 19.8\left(\mathrm{CH}_{3}\right)$.

Mass: 439 [M], 339 [M-NiPr2].

( \pm )-2-(2-Chlorophenyl)- $N, N$-diisopropylferrocenecarboxamide (( \pm )8)

By following the general procedure A, using 2-chlorophenylboronic acid (344 mg), ( \pm )-8 was obtained after column chromatography (PET-EtOAc, $10: 1)$ as an orange solid $(29.2 \mathrm{mg}, 11 \%)$. Rf (eluent: PET-EtOAc 90:10) = 0.34. Mp $82-84^{\circ} \mathrm{C}$

$v_{\max }\left(\right.$ film) $/ \mathrm{cm}^{-1} 2994,2960,2929,1621,1461,1437,1368,1339,1305$, $1212,1195,1157,1136,1035,1023,1003,813,749$.

${ }^{1} \mathrm{H} \mathrm{NMR}\left(500 \mathrm{MHz}, \mathrm{CDCl}_{3}\right): \delta(\mathrm{ppm}) 8.03(\mathrm{dd}, J=1.5,7.8 \mathrm{~Hz}, 1 \mathrm{H}, \mathrm{ArCH})$ 7.29 (dd, $J=0.8,7.8 \mathrm{~Hz}, 1 \mathrm{H}, \mathrm{ArCH}$ ), 7.22 (dt, $J=1.1,7.7 \mathrm{~Hz}, 1 \mathrm{H}, \mathrm{ArCH}), 7.16$ (dt, $J=1.5,7.7 \mathrm{~Hz}, 1 \mathrm{H}, \mathrm{ArCH}$ ), 4.70 (dd, $J=1.0,2.0 \mathrm{~Hz}, 1 \mathrm{H}, \mathrm{FcCH}$ ), 4.46 (dd, $J=1.4,2.0 \mathrm{~Hz}, 1 \mathrm{H}, \mathrm{FcCH}), 4.31(\mathrm{t}, J=2.4 \mathrm{~Hz}, 1 \mathrm{H}, \mathrm{FcCH}), 4.29(\mathrm{~s}, 5 \mathrm{H}, \mathrm{Cp})$, 3.51 (sept, $J=6.6 \mathrm{~Hz}, 1 \mathrm{H}, \mathrm{CH}), 3.13(\mathrm{sept}, J=6.8 \mathrm{~Hz}, 1 \mathrm{H}, \mathrm{CH}), 1.44(\mathrm{~d}, J=6.8$ $\left.\mathrm{Hz}, 3 \mathrm{H}, \mathrm{CH}_{3}\right), 1.21$ (d, $\left.J=6.8 \mathrm{~Hz}, 3 \mathrm{H}, \mathrm{CH}_{3}\right), 0.85\left(\mathrm{~d}, J=6.6 \mathrm{~Hz}, 3 \mathrm{H}, \mathrm{CH}_{3}\right), 0.30$ $\left(\mathrm{d}, J=6.6 \mathrm{~Hz}, 3 \mathrm{H}, \mathrm{CH}_{3}\right)$

${ }^{13} \mathrm{C}$ NMR (126 MHz, $\left.\mathrm{CDCl}_{3}\right): \delta(\mathrm{ppm}) 167.6(\mathrm{C}=0), 135.9(\mathrm{ArC}), 134.0$ $(\mathrm{ArCH}), 133.5(\mathrm{ArC}), 129.6(\mathrm{ArCH}), 128.0(\mathrm{ArCH}), 126.4(\mathrm{ArCH}), 91.9(\mathrm{FcC}-$ CO), 83.2 (FcC), $71.5(\mathrm{Cp}), 68.9(\mathrm{FcCH}), 68.8(\mathrm{FcCH}), 66.6(\mathrm{FcCH}), 50.7$ $(\mathrm{CH}), 45.8(\mathrm{CH}), 21.3\left(\mathrm{CH}_{3}\right), 21.2\left(\mathrm{CH}_{3}\right), 19.9\left(\mathrm{CH}_{3}\right), 19.6\left(\mathrm{CH}_{3}\right)$.

Mass: $313\left[\mathrm{M}-\mathrm{C}_{6} \mathrm{H}_{4} \mathrm{Cl}+\mathrm{H}\right], 213\left[\mathrm{FcCO}_{2} \mathrm{H}\right]$.

( \pm )-2-(3-Chlorophenyl)- $N, N$-diisopropylferrocenecarboxamide (( \pm )9)

By following the general procedure A, using 3-chlorophenylboronic acid (344 mg), ( $\mathbf{\pm}$ )-9 was obtained after column chromatography (PET-EtOAc, $10: 1)$ as an orange solid $(66.6 \mathrm{mg}, 28.5 \%)$. $\mathrm{R}_{\mathrm{f}}$ (eluent: PET-EtOAc 90:10) = 0.46. Mp 133-135 ${ }^{\circ} \mathrm{C}$. CCDC 1909913.

$v_{\max }\left(\right.$ film) $/ \mathrm{cm}^{-1} 2972,1617,1597,1461,1439,1368,1341,1310,1196$, 1136, 1055, 1039, 1005, 819, 810, 798, 768, 687.

${ }^{1} \mathrm{H}$ NMR (500 MHz, CDCl $): \delta(\mathrm{ppm}) 7.51(\mathrm{t}, J=1.8 \mathrm{~Hz}, 1 \mathrm{H}, \mathrm{ArCH}), 7.42(\mathrm{dt}$ $J=1.9,6.6 \mathrm{~Hz}, 1 \mathrm{H}, \mathrm{ArCH}), 7.17(\mathrm{~d}, J=4.7 \mathrm{~Hz}, 1 \mathrm{H}, \mathrm{ArCH}), 7.16(\mathrm{t}, J=1.8 \mathrm{~Hz}$ $1 \mathrm{H}, \mathrm{ArCH}), 4.45(\mathrm{~m}, 1 \mathrm{H}, \mathrm{FcCH}), 4.44(\mathrm{~m}, 1 \mathrm{H}, \mathrm{FcCH}), 4.28(\mathrm{t}, J=2.4 \mathrm{~Hz}, 1 \mathrm{H}$, $\mathrm{FcCH}$ ), 4.25 (s, 5H, Cp), 3.47 (sept, $J=6.7 \mathrm{~Hz}, 1 \mathrm{H}, \mathrm{CH}), 3.24$ (sept, $J=6.8 \mathrm{~Hz}$, $1 \mathrm{H}, \mathrm{CH}), 1.50\left(\mathrm{~d}, J=6.8 \mathrm{~Hz}, 3 \mathrm{H}, \mathrm{CH}_{3}\right), 1.42\left(\mathrm{~d}, J=6.8 \mathrm{~Hz}, 3 \mathrm{H}, \mathrm{CH}_{3}\right), 0.85(\mathrm{~d}, J$ $\left.=6.7 \mathrm{~Hz}, 3 \mathrm{H}, \mathrm{CH}_{3}\right), 0.35\left(\mathrm{~d}, J=6.7 \mathrm{~Hz}, 3 \mathrm{H}, \mathrm{CH}_{3}\right)$.

${ }^{13} \mathrm{C} \mathrm{NMR}\left(126 \mathrm{MHz}, \mathrm{CDCl}_{3}\right): \delta(\mathrm{ppm}) 167.8(\mathrm{C}=0), 140.7(\mathrm{ArC}), 134.2(\mathrm{ArC})$, 129.5 (ArCH), 127.9 (ArCH), 126.7 (ArCH), 126.3 (ArCH), 90.3 (FcC-CO), $83.2(\mathrm{FcC}), 71.6(\mathrm{Cp}), 70.1(\mathrm{FcCH}), 67.4(\mathrm{FcCH}), 64.9(\mathrm{FcCH}), 50.9(\mathrm{CH})$, $46.0(\mathrm{CH}), 21.3\left(\mathrm{CH}_{3}\right), 21.1\left(\mathrm{CH}_{3}\right), 20.0\left(\mathrm{CH}_{3}\right), 19.7\left(\mathrm{CH}_{3}\right)$.

Mass: 423 [M], 323 [M-NiPr $], 296$ [M-CONiPr $2+\mathrm{H}]$.

(士)- $N, N$-Diisopropyl-2-(4-trifluoromethylphenyl)ferrocenecarboxamide $(( \pm)-10)$

By following the general procedure A, using 4(trifluoromethyl)phenylboronic acid (417 mg), ( $\mathbf{( ) - 1 0}$ was obtained after column chromatography (PET-EtOAc, 10:1) as an orange solid (52.0 mg, 20.5\%). R $\mathrm{R}_{\mathrm{f}}$ (eluent: PET-EtOAc 90:10) $=0.50$. Mp 179-181 ${ }^{\circ} \mathrm{C}$. CCDC 1909915.

$v_{\max }\left(\right.$ film) $/ \mathrm{cm}^{-1} 2965,2932,2234,1613,1463,1319,1162,1121,1106$, 1068, 906, 818, 727

${ }^{1} \mathrm{H}$ NMR (500 MHz, $\mathrm{CDCl}_{3}$ ): $\delta(\mathrm{ppm}) 7.65(\mathrm{~d}, J=8.0 \mathrm{~Hz}, 2 \mathrm{H}, 2 \mathrm{x} \mathrm{ArCH}), 7.49$ (d, $J=8.0 \mathrm{~Hz}, 2 \mathrm{H}, 2 \mathrm{xArCH}), 4.50(\mathrm{~s}, 1 \mathrm{H}, \mathrm{FcCH}), 4.47(\mathrm{~s}, 1 \mathrm{H}, \mathrm{FcCH}), 4.32$ (s, $1 \mathrm{H}, \mathrm{FcH}$ ), 4.25 (s, 5H, Cp), 3.48 (sept, $J=6.7 \mathrm{~Hz}, 1 \mathrm{H}, \mathrm{CH}$ ), 3.25 (sept, $J=6.7$ $\mathrm{Hz}, 1 \mathrm{H}, \mathrm{CH}), 1.50$ (d, J=6.7 Hz, 3H, $\left.\mathrm{CH}_{3}\right), 1.40\left(\mathrm{~d}, J=6.7 \mathrm{~Hz}, 3 \mathrm{H}, \mathrm{CH}_{3}\right), 0.87$ (d, $\left.J=6.7 \mathrm{~Hz}, 3 \mathrm{H}, \mathrm{CH}_{3}\right), 0.34\left(\mathrm{~d}, J=6.7 \mathrm{~Hz}, 3 \mathrm{H}, \mathrm{CH}_{3}\right)$.

${ }^{13} \mathrm{C}$ NMR (126 MHz, $\mathrm{CDCl}_{3}$ ): $\delta(\mathrm{ppm}) 167.8$ (s, C=0), 142.9 (s, ArC), 128.6 $\left(\mathrm{q}, J=32.6 \mathrm{~Hz}, \mathrm{ArC}-\mathrm{CF}_{3}\right), 128.2(\mathrm{~s}, 2 \times \mathrm{ArCH}), 124.5\left(\mathrm{q}, J=271.9 \mathrm{~Hz}, \mathrm{CF}_{3}\right)$, 125.2 (q, $J=3.5 \mathrm{~Hz}, 2$ x ArCH), 90.7 (s, FcC-CO), 82.9 (s, FcC), 71.7 (s, Cp), $70.3(\mathrm{~s}, \mathrm{FcCH}), 67.6(\mathrm{~s}, \mathrm{FcCH}), 65.1(\mathrm{~s}, \mathrm{FcCH}), 50.9(\mathrm{~s}, \mathrm{CH}), 46.0(\mathrm{~s}, \mathrm{CH}), 21.3$ $\left(\mathrm{s}, \mathrm{CH}_{3}\right), 21.0\left(\mathrm{~s}, \mathrm{CH}_{3}\right), 20.1\left(\mathrm{~s}, \mathrm{CH}_{3}\right), 19.8\left(\mathrm{~s}, \mathrm{CH}_{3}\right)$.

${ }^{19} \mathrm{~F}$ NMR $\left(282 \mathrm{MHz}, \mathrm{CDCl}_{3}\right): \delta(\mathrm{ppm})-62.4(\mathrm{~s})$. 
Mass: 457 [M], 357 [M-NiPr 2 , 330 [M-CONiPr $2+\mathrm{H}]$.

\section{General procedure B: Ullmann-type cross-coupling of ( \pm )-2}

Compound ( \pm )-2 (263 mg, $0.60 \mathrm{mmol}, 1.00$ equiv), carboxylic acid ( $0.72 \mathrm{mmol}, 1.20$ equiv) and $\mathrm{Cu}_{2} \mathrm{O}(103 \mathrm{mg}, 0.72 \mathrm{mmol}, 1.20$ equiv) were placed in a dried Schlenk tube, subjected to three cycles of vacuum/argon Acetonitrile $(8.50 \mathrm{~mL})$ was added and the reaction mixture was stirred overnight at $90{ }^{\circ} \mathrm{C}$ (external temperature) in a pre-heated oil bath. The reaction mixture was cooled to rt, filtered over a pad of Celite, washed with EtOAc until colorless. The filtrate was concentrated under vacuum using a rotary evaporator to give the crude product. This was purified by column chromatography over $\mathrm{SiO}_{2}$, using PET-EtOAc (proportions given for each product) to give the title product.

\section{$( \pm)-N, N$-Diisopropyl-2-(4-fluorobenzoyl)ferrocenecarboxamide}

\section{((士)-11)}

By following the general procedure B, using 4-fluorobenzoic acid (101 $\mathrm{mg}$ ), ( $\mathbf{\pm}$ )-11 was obtained after column chromatography (PET-EtOAc $10: 1$ to $90: 10,1 \%$ of $\mathrm{NEt}_{3}$ ) as an orange solid (230 $\left.\mathrm{mg}, 85 \%\right)$. Rf (eluent: PET-EtOAc 90:10) = 0.50. Mp 142-144 ${ }^{\circ} \mathrm{C}$. CCDC 1909916.

$v_{\max }\left(\right.$ film) $/ \mathrm{cm}^{-1} 2967,1744,1736,1632,1598,1507,1471,1435,1371$ $1321,1262,1246,1224,1155,1134,1081,1063,1041,1012,1003,866$, $812,763,757,686$.

${ }^{1} \mathrm{H}$ NMR (300 MHz, $\left.\mathrm{CDCl}_{3}\right): \delta(\mathrm{ppm}) 8.10(\mathrm{dd}, J=5.5,8.9 \mathrm{~Hz}, 2 \mathrm{H}, 2 \times \mathrm{ArCH})$ $7.11(\mathrm{t}, J=8.6 \mathrm{~Hz}, 2 \mathrm{H}, 2 \times \mathrm{ArCH}), 4.64(\mathrm{dd}, J=1.5,2.6 \mathrm{~Hz}, 1 \mathrm{H}, \mathrm{FcCH}), 4.38$ (s, 5H, Cp), $4.12(\mathrm{dd}, J=1.5,2.7 \mathrm{~Hz}, 1 \mathrm{H}, \mathrm{FcCH}), 4.06(\mathrm{br} \mathrm{s}, 1 \mathrm{H}, \mathrm{CH}), 4.00(\mathrm{t}$ $J=2.7 \mathrm{~Hz}, 1 \mathrm{H}, \mathrm{FcCH}), 3.36(\mathrm{br} \mathrm{s}, 1 \mathrm{H}, \mathrm{CH}), 1.45\left(\mathrm{br} \mathrm{s}, 3 \mathrm{H}, \mathrm{CH}_{3}\right), 1.37(\mathrm{br} \mathrm{s}$ $3 \mathrm{H}, \mathrm{CH}_{3}$ ), 1.05 (br s, 3H, $\mathrm{CH}_{3}$ ), 0.99 (br s, 3H, $\mathrm{CH}_{3}$ ).

${ }^{13} \mathrm{C}$ NMR (75.4 MHz, $\left.\mathrm{CDCl}_{3}\right): \delta(\mathrm{ppm}) 166.2(\mathrm{~d}, J=254.7 \mathrm{~Hz}, \mathrm{ArC}-\mathrm{F}), 165.8$ (s, C=O amide), 164.4 (s, C=Oester), 132.7 (d, $J=9.4 \mathrm{~Hz}, 2 \times \mathrm{ArCH}$ ), 126.0 (d, = $2.8 \mathrm{~Hz}, \mathrm{ArC}$ ), 115.9 (d, J = 22.2 Hz, 2 x ArCH), 115.2 (s; FcC-0), 80.1 (s, $\mathrm{FcC}$ ), 71.4 (s, Cp), 62.8 (s, FcCH), 62.1 (s, FcCH), 61.1 (s, FcCH), 50.7 (s, CH), $46.1(\mathrm{~s}, \mathrm{CH}), 20.8\left(\mathrm{~s}, 4 \times \mathrm{CH}_{3}\right)$.

\section{Mass: 451 [M], 328, 229.}

$\left(S_{p}\right)-N, N$-Diisopropyl-2-(4-fluorobenzoyl)ferrocenecarboxamide ( $\left(S_{p}\right.$ )-11)

By following the general procedure B, using $\left(S_{p}\right)$-2-iodo- $N, N$ diisopropylferrocenecarboxamide (er 87:13, $80.0 \mathrm{mg}$ ) and 4fluorobenzoic acid (30.3 mg), $\left(\boldsymbol{S}_{\boldsymbol{p}}\right) \mathbf{- 1 1}$ was obtained after column chromatography (PET-EtOAc, 10:1 to $90: 10,1 \%$ of $\mathrm{NEt}_{3}$ ) as an orange solid $\left(62 \mathrm{mg}, 76 \%, 89: 11 \mathrm{er}\right.$ ). $[\alpha]_{\mathrm{D}}-1.09$ (c 0.01 in $\left.\mathrm{CHCl}_{3}\right)$. The enantiomeric ratio was determined on Chiralpak IC-3 column, hexaneiPrOH: 98:2, $1.0 \mathrm{~mL} / \mathrm{min}, 20^{\circ} \mathrm{C}, \lambda=254 \mathrm{~nm}$, t (major) $=16.50 \mathrm{~min}$, (minor) $=19.41 \mathrm{~min}$.

\section{( \pm )- $N, N$-Diisopropyl-2-(2-naphthoyl)ferrocenecarboxamide $\quad(( \pm)$ -} 12)

By following the general procedure B, using 2-naphthoic acid (126 mg), ( \pm )-12 was obtained after column chromatography (PET-EtOAc, 10:1 to $90: 10,1 \%$ of $\left.\mathrm{NEt}_{3}\right)$ as an orange solid $\left(290 \mathrm{mg}\right.$, quant.). R $\mathrm{R}_{\mathrm{f}}$ (eluent: PETEtOAc 90:10) $=0.43 . \mathrm{Mp} 145-147^{\circ} \mathrm{C}$

$v_{\max }$ (film) $/ \mathrm{cm}^{-1} 2978,1732,1626,1472,1429,1318,1265,1217,1189$ 1134, 1082, 1004, 951, 876, 834, 814, 778 .

${ }^{1} \mathrm{H}$ NMR (300 MHz, CDCl 3$): \delta(\mathrm{ppm}) 8.67$ (s, 1H, ArCH), 8.10 (dd, J= 1.7, 8.6 $\mathrm{Hz}, 1 \mathrm{H}, \mathrm{ArCH}), 7.96(\mathrm{~d}, J=8.6 \mathrm{~Hz}, 1 \mathrm{H}, \mathrm{ArCH}), 7.89(\mathrm{~d}, J=6.2 \mathrm{~Hz}, 1 \mathrm{H}, \mathrm{ArCH})$ $7.87(\mathrm{~d}, J=5.4 \mathrm{~Hz}, 1 \mathrm{H}, \mathrm{ArCH}), 7.56(\mathrm{~m}, 2 \mathrm{H}, 2 \mathrm{x} \mathrm{ArCH}), 4.75(\mathrm{dd}, J=1.4,2.5$ $\mathrm{Hz}, 1 \mathrm{H}, \mathrm{FcCH}), 4.43$ (s, 5H, Cp), 4.16 (dd, $J=1.4,2.5 \mathrm{~Hz}, 1 \mathrm{H}, \mathrm{FcCH}), 4.08$ (br $\mathrm{s}, 1 \mathrm{H}, \mathrm{CH}), 4.04(\mathrm{t}, J=2.7 \mathrm{~Hz}, 1 \mathrm{H}, \mathrm{FcCH}), 3.39(\mathrm{br} \mathrm{s}, 1 \mathrm{H}, \mathrm{CH}), 1.47($ br s, $6 \mathrm{H}$, $2 \times \mathrm{CH}_{3}$ ), 1.02 (br s, 6H, $2 \times \mathrm{CH}_{3}$ ).

${ }^{13} \mathrm{C}$ NMR (75.4 MHz, $\mathrm{CDCl}_{3}$ ): $\delta$ (ppm) 165.8 (s, C=0 amide), 165.4 (s, C=0 $=\mathrm{O}_{\text {ester }}$ ), 135.9 (ArC), 132.7 (ArC), 131.8 (ArCH), 129.7 ( $\mathrm{ArCH}), 128.7(\mathrm{ArCH}), 128.5$ $(\mathrm{ArCH}), 127.9(\mathrm{ArCH}), 126.9(\mathrm{ArCH}), 125.5(\mathrm{ArCH}), 114.9(\mathrm{FcC}-\mathrm{O}), 80.6$ (FcC), $71.4(\mathrm{Cp}), 62.9(\mathrm{FcCH}), 62.1(\mathrm{FcCH}), 61.0(\mathrm{FcCH}), 50.7(\mathrm{CH}), 46.1$ (CH), $20.9\left(4 \times \mathrm{CH}_{3}\right)$

Mass: $313\left[\mathrm{M}-\mathrm{C}_{11} \mathrm{H}_{7} \mathrm{O}_{2}+\mathrm{H}\right]$.

( \pm )- $N, N$-Diisopropyl-2-(2,4-dimethylbenzoyl)ferrocenecarboxamide ((士)-13)

By following the general procedure B, using 2,4-dimethylbenzoic acid (108 mg), ( \pm )-13 was obtained after column chromatography (PETEtOAc, 90:10, 1\% of $\mathrm{NEt}_{3}$ ) as an orange solid (242 mg, 87\%). Rf (eluent: PET-EtOAc 10:1) = 0.28. Mp 152-154 ${ }^{\circ} \mathrm{C}$. CCDC 1909919.

$v_{\max }($ film $) / \mathrm{cm}^{-1} 2958,1715,1620,1463,1430,1323,1288,1252,1236$,
${ }^{1} \mathrm{H}$ NMR $\left(300 \mathrm{MHz}, \mathrm{CDCl}_{3}\right): \delta(\mathrm{ppm}) 7.95(\mathrm{~d}, J=8.4 \mathrm{~Hz}, 1 \mathrm{H}, \mathrm{ArCH}), 7.07-$ $7.05(\mathrm{~m}, 2 \mathrm{H}, 2 \mathrm{x} \mathrm{ArCH}), 4.60$ (dd, $J=1.5,2.6 \mathrm{~Hz}, 1 \mathrm{H}, \mathrm{FcCH}), 4.39$ (s, 5H, Cp), 4.12 (dd, $J=1.5,2.6 \mathrm{~Hz}, 1 \mathrm{H}, \mathrm{FcCH}), 4.06(\mathrm{br} \mathrm{s}, 1 \mathrm{H}, \mathrm{CH}), 4.00(\mathrm{t}, J=2.6 \mathrm{~Hz}$, $1 \mathrm{H}, \mathrm{FcCH}), 3.35(\mathrm{br} \mathrm{s}, 1 \mathrm{H}, \mathrm{CH}), 2.59\left(\mathrm{~s}, 3 \mathrm{H}, \mathrm{CH}_{3}\right), 2.34\left(\mathrm{~s}, 3 \mathrm{H}, \mathrm{CH}_{3}\right), 1.46(\mathrm{br}$ s, $3 \mathrm{H}, \mathrm{CH}_{3}$ ), 1.38 (br s, $3 \mathrm{H}, \mathrm{CH}_{3}$ ), 1.03 (br s, $\left.3 \mathrm{H}, \mathrm{CH}_{3}\right), 0.98$ (br s, $3 \mathrm{H}, \mathrm{CH}_{3}$ ).

${ }^{13} \mathrm{C}$ NMR (75.4 MHz, $\left.\mathrm{CDCl}_{3}\right): \delta(\mathrm{ppm}) 166.2(\mathrm{C}=0), 165.9(\mathrm{C}=0), 143.3$ (ArC), $141.0(\mathrm{ArC}), 132.7(\mathrm{ArCH}), 131.7(\mathrm{ArCH}), 126.8(\mathrm{ArCH}), 125.9$ (ArC), 114.9 (FcC-O), $80.7(\mathrm{FcC}), 71.3(\mathrm{Cp}), 62.8(\mathrm{FcCH}), 62.1(\mathrm{FcCH}), 61.2$ $(\mathrm{FcCH}), 50.7(\mathrm{CH}), 46.0(\mathrm{CH}), 22.0\left(\mathrm{CH}_{3}\right), 21.6\left(\mathrm{CH}_{3}\right), 20.8\left(2 \mathrm{x} \mathrm{CH}_{3}\right)$.

Mass: $461[\mathrm{M}]$.

(士)-2-(2-Acetoxyphenyl)- $N, N$-diisopropylferrocenecarboxamide (( \pm -14)

By following the general procedure B, using 2-acetoxybenzoic acid (130 mg), ( $\mathbf{\pm}$-14 was obtained after column chromatography (PET-EtOAc, $10: 1$ to $90: 10,1 \%$ of $\mathrm{NEt}_{3}$ ) as an orange solid (212 $\left.\mathrm{mg}, 72 \%\right)$. $\mathrm{R}_{\mathrm{f}}$ (eluent: PET-EtOAc 90:10) = 0.42. Mp 157-159 ${ }^{\circ} \mathrm{C}$. CCDC 1909918

$v_{\max }($ film $) / \mathrm{cm}^{-1} 2966,1764,1736,1624,1604,1474,1431,1321,1242$, 1212, 1182, 1156, 1051, 1002, 911, 818, 754, 696.

${ }^{1} \mathrm{H}$ NMR (300 MHz, CDCl 3$): \delta(\mathrm{ppm}) 8.13(\mathrm{dd}, J=1.7,7.8 \mathrm{~Hz}, 1 \mathrm{H}, \mathrm{ArCH})$ $7.56(\mathrm{dt}, J=1.7,7.8 \mathrm{~Hz}, 1 \mathrm{H}, \mathrm{ArCH}), 7.32(\mathrm{dt}, J=1.7,7.8 \mathrm{~Hz}, 1 \mathrm{H}, \mathrm{ArCH}), 7.09$ (dd, $J=1.7,7.8 \mathrm{~Hz}, 1 \mathrm{H}, \mathrm{ArCH}), 4.56(\mathrm{dd}, J=1.4,2.5 \mathrm{~Hz}, 1 \mathrm{H}, \mathrm{FcCH}), 4.38$ (s, $5 \mathrm{H}, \mathrm{Cp}), 4.12(\mathrm{dd}, J=1.4,2.6 \mathrm{~Hz}, 1 \mathrm{H}, \mathrm{FcCH}), 4.04(\mathrm{br} \mathrm{s}, 1 \mathrm{H}, \mathrm{CH}), 4.00(\mathrm{t}, J=$ $2.6 \mathrm{~Hz}, 1 \mathrm{H}, \mathrm{FcCH}), 3.34$ (br s, $1 \mathrm{H}, \mathrm{CH}), 2.34\left(\mathrm{CH}_{3}\right), 1.44$ (br s, 3H, $\left.\mathrm{CH}_{3}\right), 1.38$ (br s, $3 \mathrm{H}, \mathrm{CH}_{3}$ ), 1.02 (br s, $\left.3 \mathrm{H}, \mathrm{CH}_{3}\right), 0.96\left(\right.$ br s, $3 \mathrm{H}, \mathrm{CH}_{3}$ ).

${ }^{13} \mathrm{C}$ NMR (75.4 MHz, $\left.\mathrm{CDCl}_{3}\right): \delta(\mathrm{ppm}) 169.6\left(\mathrm{C}=\mathrm{O}_{\text {acetate }}\right), 165.6\left(\mathrm{C}=\mathrm{O}_{\text {amide}}\right)$, $163.1\left(\mathrm{C}=\mathrm{O}_{\text {ester }}\right), 151.1(\mathrm{ArC}), 134.5(\mathrm{ArCH}), 132.3(\mathrm{ArCH}), 126.3(\mathrm{ArCH})$, 124.1 (ArCH), 122.6 (ArC-O), 114.7 (FcC-O), 80.4 (FcC), 71.3 (Cp), 62.9 $(\mathrm{FcCH}), 62.1(\mathrm{FcCH}), 61.2(\mathrm{FcCH}), 50.6(\mathrm{CH}), 46.0(\mathrm{CH}), 21.2\left(\mathrm{CH}_{3}\right), 20.7(2$ $\left.\mathrm{x} \mathrm{CH}_{3}\right)$.

Mass: $491[\mathrm{M}], 329\left[\mathrm{M}-\mathrm{C}_{9} \mathrm{H}_{7} \mathrm{O}_{3}+\mathrm{H}\right]$.

Bis ( \pm )- $N, N$-Diisopropyl-2-(1,4-phenyldioyl)ferrocenecarboxamide (( \pm -15)

By following the general procedure B, using terephtalic acid ( $49.8 \mathrm{mg}, 0.30$ mmol, 0.50 equiv), ( $\mathbf{(}) \mathbf{- 1 5}$ was obtained after column chromatography (PET-EtOAc, 10:1 to $90: 10,1 \%$ of $\mathrm{NEt}_{3}$ ) as a red solid $(193 \mathrm{mg}, 49 \%) . \mathrm{R}_{\mathrm{f}}$ (eluent: PET-EtOAc 10:1) $=0.18 . \mathrm{Mp} 70-75^{\circ} \mathrm{C}$.

$v_{\max }\left(\right.$ film) $/ \mathrm{cm}^{-1} 2965,1737,1627,1464,1431,1319,1241,1211,1134$, $1085,1017,814,720$.

${ }^{1} \mathrm{H}$ NMR (300 MHz, $\left.\mathrm{CDCl}_{3}\right): \delta(\mathrm{ppm}) 8.18(\mathrm{~s}, 2 \mathrm{H}, 2 \times \mathrm{ArCH}), 8.17(\mathrm{~s}, 2 \mathrm{H}, 2 \mathrm{x}$ $\mathrm{ArCH}$ ), 4.69 (dd, $J=1.4,2.4 \mathrm{~Hz}, 2 \mathrm{H}, 2 \mathrm{x} \mathrm{FCCH}$ ), 4.40 (s, 10H, 2x Cp), 4.15 (dd, $J=1.2,2.4 \mathrm{~Hz}, 2 \mathrm{H}, 2 \times \mathrm{FcCH}), 4.09(\mathrm{br} \mathrm{s}, 2 \mathrm{H}, 2 \times \mathrm{CH}), 4.03(\mathrm{t}, J=2.6 \mathrm{~Hz}$, $2 \mathrm{H}, 2 \times \mathrm{FcCH}$ ), 3.39 (br s, $2 \mathrm{H}, 2 \times \mathrm{CH}$ ), 1.47 (br s, $6 \mathrm{H}, 2 \times \mathrm{CH}_{3}$ ), 1.41 (br s, $6 \mathrm{H}, 2 \mathrm{x} \mathrm{CH}_{3}$ ), 1.06 (br s, 6H, $2 \mathrm{x} \mathrm{CH}_{3}$ ), 1.02 (br s, 6H, $2 \mathrm{x} \mathrm{CH}_{3}$ ).

$\left.{ }^{13} \mathrm{C} \mathrm{NMR} \mathrm{(75.4} \mathrm{MHz,} \mathrm{CDCl}_{3}\right): \delta(\mathrm{ppm}) 165.6\left(2 \times \mathrm{C}=\mathrm{O}_{\text {amide }}\right), 164.3\left(\mathrm{C}=\mathrm{O}_{\text {ester }}\right)$, $164.2\left(\mathrm{C}=\mathrm{O}_{\text {ester }}\right), 133.7$ ( $\left.2 \times \mathrm{ArC}\right), 130.0$ ( $\left.4 \mathrm{x} \mathrm{ArCH}\right), 115.0$ (FcC-O), 114.9 (FcC-0), 79.9 ( 2 x FcC), 71.3 ( $2 \times \mathrm{Cp}), 62.8$ (FcCH), 62.7 (FcCH), $62.0(2 \times$ $\mathrm{FcCH}), 60.8(\mathrm{FcCH}), 60.7(\mathrm{FcCH}), 55.5(\mathrm{CH}), 50.5(\mathrm{CH}), 45.9(2 \times \mathrm{CH}), 20.7$ $\left(8 \times \mathrm{CH}_{3}\right)$.

( \pm )- $N, N$-Diisopropyl-2-(ferrocenoyl)ferrocenecarboxamide (( \pm$)-16)$ By following the general procedure B, using ferrocenecarboxylic acid $(165$ $\mathrm{mg}$, ( $\mathbf{\pm}$-16 was obtained after column chromatography (PET-EtOAc, $90: 10,1 \%$ of $\left.\mathrm{NEt}_{3}\right)$ as an orange solid $(277 \mathrm{mg}, 85 \%)$. $\mathrm{R}_{\mathrm{f}}$ (eluent: PETEtOAc 10:1) $=0.26 . \mathrm{Mp} \mathrm{58-62}{ }^{\circ} \mathrm{C}$. CCDC 1909917.

$v_{\max }\left(\right.$ film) $/ \mathrm{cm}^{-1} 2959,1727,1626,1467,1429,1374,1317,1267,1245$, $1134,1104,1027,1002,910,817,804$.

$\left.{ }^{1} \mathrm{H} \mathrm{NMR} \mathrm{(300} \mathrm{MHz,} \mathrm{CDCl} 3\right): \delta(\mathrm{ppm}) 4.85(\mathrm{~m}, 1 \mathrm{H}, \mathrm{FcCH}), 4.83(\mathrm{~m}, 1 \mathrm{H}, \mathrm{FcCH})$, 4.61 (dd, $J=1.5,2.5 \mathrm{~Hz}, 1 \mathrm{H}, \mathrm{FcCH}), 4.43(\mathrm{t}, J=1.7 \mathrm{~Hz}, 2 \mathrm{H}, 2 \mathrm{x} \mathrm{FcCH}$ ), 4.39 (s, 5H, Cp), 4.28 (s, 5H, Cp), 4.09 (dd, J = 1.5, $2.5 \mathrm{~Hz}, 1 \mathrm{H}, \mathrm{FcCH}), 4.02$ (br s, $1 \mathrm{H}, \mathrm{CH}$ ), $3.98(\mathrm{t}, J=2.5 \mathrm{~Hz}, 1 \mathrm{H}, \mathrm{FcCH}$ ), 3.40 (br s, $1 \mathrm{H}, \mathrm{CH}), 1.50$ (br s, $6 \mathrm{H}, 2$ $\mathrm{x} \mathrm{CH}_{3}$ ), 1.05 (br s, 6H, $2 \times \mathrm{CH}_{3}$ ).

${ }^{13} \mathrm{C}$ NMR (75.4 MHz, $\mathrm{CDCl}_{3}$ ): $\delta(\mathrm{ppm}) 169.7$ ( $\left.2 \times \mathrm{C}=\mathrm{O}_{\text {ester }}\right), 165.7\left(\mathrm{C}=\mathrm{O}_{\text {amide }}\right.$ ), 114.5 (FcC-O), 80.2 (FcC-COamide), 71.7 (2 x FcCH), 71.1 (Cp), 70.4 (2 x $\mathrm{FcCH}$ ), 70.3 (FcC-COester), 70.0 (Cp), 62.5 (FcCH), 61.9 (FcCH), $60.6(\mathrm{FcCH})$ $50.6(\mathrm{CH}), 45.8(\mathrm{CH}), 21.0\left(4 \mathrm{x} \mathrm{CH}_{3}\right)$.

( \pm )- $N, N$-Diisopropyl-2-(2-thiophenoyl)ferrocenecarboxamide $(( \pm)-$ 17)

By following the general procedure B, using 2-thiophenecarboxylic acid (92.3 mg), ( $\mathbf{\pm}$-17 was obtained after column chromatography (PETEtOAc, $10: 1,1 \%$ of $\mathrm{NEt}_{3}$ ) as an orange solid (204 mg, 77\%). $\mathrm{R}_{\mathrm{f}}$ (eluent: PET-EtOAc 90:10) $=0.40$. Mp $118-120^{\circ} \mathrm{C}$. 
$\nu_{\max }\left(\right.$ film) $/ \mathrm{cm}^{-1} 2966,1721,1632,1615,1463,1410,1357,1317,1247$, 1223, 1208, 1079, 1057, 1038, 1022, 1001, 812, 742, 735.

${ }^{1} \mathrm{H}$ NMR (300 MHz, $\left.\mathrm{CDCl}_{3}\right): \delta(\mathrm{ppm}) 7.86(\mathrm{dd}, J=1.3,3.8 \mathrm{~Hz}, 1 \mathrm{H}, \mathrm{ArCH})$ 7.59 (dd, $J=1.3,5.0 \mathrm{~Hz}, 1 \mathrm{H}, \mathrm{ArCH}$ ), 7.11 (dd, $J=3.8,5.0 \mathrm{~Hz}, 1 \mathrm{H}, \mathrm{ArCH}$ ), 4.66 $(\mathrm{dd}, J=1.5,2.6 \mathrm{~Hz}, 1 \mathrm{H}, \mathrm{FcCH}), 4.11(\mathrm{dd}, J=1.5,2.6 \mathrm{~Hz}, 1 \mathrm{H}, \mathrm{FcCH}), 4.04(\mathrm{br}$ $\mathrm{s}, 1 \mathrm{H}, \mathrm{CH}), 3.99(\mathrm{t}, J=2.6 \mathrm{~Hz}, 1 \mathrm{H}, \mathrm{FcCH}), 3.38(\mathrm{br} \mathrm{s}, 1 \mathrm{H}, \mathrm{CH}), 1.44(\mathrm{br} \mathrm{s}, 6 \mathrm{H}$, $2 \mathrm{x} \mathrm{CH}_{3}$ ), 1.02 (br s, $6 \mathrm{H}, 2 \times \mathrm{CH}_{3}$ ).

${ }^{13} \mathrm{C}$ NMR (75.4 MHz, $\left.\mathrm{CDCl}_{3}\right): \delta(\mathrm{ppm}) 165.6$ (C=Oamide), $160.5\left(\mathrm{C}=\mathrm{O}_{\text {ester }}\right.$ ), 134.4 (ArCH), $133.5(\mathrm{ArCH}), 13.1(\mathrm{ArC}), 128.1(\mathrm{ArCH}), 114.6$ (FcC-CO), $80.4(\mathrm{FcC}), 71.4(\mathrm{Cp}), 62.9(\mathrm{FcCH}), 62.1(\mathrm{FcCH}), 60.7(\mathrm{FcCH}), 50.7(\mathrm{CH})$ $46.0(\mathrm{CH}), 20.8\left(4 \times \mathrm{CH}_{3}\right)$.

Mass: 439 [M], 328, 229.

( \pm )- $N, N$-Diisopropyl-2-(3,4-methylenedioxycinnamoyl)ferrocenecarboxamide $(( \pm)-18)$

By following the general procedure B, using 3,4-methylenedioxycinnamic acid $(138 \mathrm{mg}), \mathbf{(} \mathbf{\pm}) \mathbf{- 1 8}$ was obtained after column chromatography (PETEtOAc, 90:10,1\% of $\mathrm{NEt}_{3}$ ) as an orange solid (267 mg, 88\%). $\mathrm{R}_{\mathrm{f}}$ (eluent: PET-EtOAc 90:10) = 0.22. Mp 153-155 ${ }^{\circ} \mathrm{C}$.

$\nu_{\max }\left(\right.$ film) $/ \mathrm{cm}^{-1} 2967,1730,1628,1601,1500,1490,1464,1447,1430$ $1367,1317,1299,1247,1136,1119,1100,1032,1006,926,817,751$.

${ }^{1} \mathrm{H}$ NMR (300 MHz, $\left.\mathrm{CDCl}_{3}\right): \delta(\mathrm{ppm}) 7.64(\mathrm{~d}, J=15.9 \mathrm{~Hz}, 1 \mathrm{H}, \mathrm{CH}=\mathrm{CH}=\mathrm{CO})$ $7.04(\mathrm{~d}, J=1.7 \mathrm{~Hz}, 1 \mathrm{H}, \mathrm{ArCH}), 7.01$ (dd, $J=1.7,7.9 \mathrm{~Hz}, 1 \mathrm{H}, \mathrm{ArCH}), 6.80$ (d, $=7.9 \mathrm{~Hz}, 1 \mathrm{H}, \mathrm{ArCH}), 6.34(\mathrm{~d}, J=15.9 \mathrm{~Hz}, 1 \mathrm{H}, \mathrm{CH}=\mathrm{CH}=\mathrm{CO}), 6.00\left(\mathrm{~s}, 2 \mathrm{H}, \mathrm{CH}_{2}\right)$, 4.56 (dd, $J=1.4,2.4 \mathrm{~Hz}, 1 \mathrm{H}, \mathrm{FcCH}$ ), $4.37(\mathrm{~s}, 5 \mathrm{H}, \mathrm{Cp}$ ), 4.11 (dd, $J=1.5,2.6 \mathrm{~Hz}$ $1 \mathrm{H}, \mathrm{FcCH}), 4.05$ (br s, 1H, CH), 3.98 (t, $J=2.6 \mathrm{~Hz}, 1 \mathrm{H}, \mathrm{FcCH}), 3.37(\mathrm{br} \mathrm{s}, 1 \mathrm{H}$ $\mathrm{CH}), 1.45$ (br s, 6H, $2 \mathrm{x} \mathrm{CH}_{3}$ ), 1.04 (br s, 6H, $2 \times \mathrm{CH}_{3}$ ).

${ }^{13} \mathrm{C}$ NMR (75.4 MHz, $\mathrm{CDCl}_{3}$ ): $\delta(\mathrm{ppm}) 165.9(\mathrm{C}=0), 165.8(\mathrm{C}=0), 150.1$ (ArC 0), 148.6 (ArC-O), $145.9(\mathrm{CH}=\mathrm{CH}=\mathrm{CO}), 128.9(\mathrm{ArC}), 125.0(\mathrm{ArCH}), 115.3$ $(\mathrm{CH}=\mathrm{CH}=\mathrm{CO}), 114.8(\mathrm{FcC}-\mathrm{CO}), 108.8(\mathrm{ArCH}), 106.8(\mathrm{ArCH}), 101.8\left(\mathrm{CH}_{2}\right)$ $80.0(\mathrm{FcC}), 71.4(\mathrm{Cp}), 63.0(\mathrm{FcCH}), 62.0(\mathrm{FcCH}), 61.1(\mathrm{FcCH}), 50.7(\mathrm{CH})$ $46.1(\mathrm{CH}), 21.0\left(4 \times \mathrm{CH}_{3}\right)$.

( \pm )- $N, N$-Diisopropyl-2-(piperoyl)ferrocenecarboxamide (( \pm$)-19)$

By following the general procedure $B$, using piperic acid (157 mg), ( $\mathbf{\pm})-\mathbf{1 9}$ was obtained after column chromatography (PET-EtOAc, 90:10 to 80:20 $1 \%$ of $\mathrm{NEt}_{3}$ ) as an orange solid (291 mg, 92\%). $\mathrm{R}_{\mathrm{f}}$ (eluent: PET-EtOAc $90: 10)=0.23 . \mathrm{Mp} 59-64^{\circ} \mathrm{C}$.

$v_{\max }$ (film) $/ \mathrm{cm}^{-1} 2965,1722,162,1605,1489,1446,1433,1368,1320$ $1521,1227,1203,1108,1036,997,928,814,754$.

${ }^{1} \mathrm{H}$ NMR (300 MHz, $\mathrm{CDCl}_{3}$ ): $\delta(\mathrm{ppm}) 7.48$ (dd, $J=10.7,15.2 \mathrm{~Hz}, 1 \mathrm{H}$ $\mathrm{CH}=\mathrm{CH}=\mathrm{CH}=\mathrm{CH}=\mathrm{CO}), 6.99(\mathrm{~d}, J=1.6 \mathrm{~Hz}, 1 \mathrm{H}, \mathrm{ArCH}), 6.92(\mathrm{dd}, J=1.6,8.1$ $\mathrm{Hz}, 1 \mathrm{H}, \mathrm{ArCH}), 6.84(\mathrm{~d}, J=15.5 \mathrm{~Hz}, 1 \mathrm{H}, \mathrm{CH}=\mathrm{CH}=\mathrm{CH}=\mathrm{CH}=\mathrm{CO}), 6.78(\mathrm{~d}, J=8.1$ $\mathrm{Hz}, 1 \mathrm{H}, \mathrm{ArCH}$ ), 6.71 (dd, $J=10.7,15.5 \mathrm{~Hz}, 1 \mathrm{H}, \mathrm{CH}=\mathrm{CH}=\mathrm{CH}=\mathrm{CH}=\mathrm{CO}$ ), 6.01 (d, $J=15.2 \mathrm{~Hz}, 1 \mathrm{H}, \mathrm{CH}=\mathrm{CH}=\mathrm{CH}=\mathrm{CH}=\mathrm{CO}), 5.98\left(\mathrm{~s}, 2 \mathrm{H}, \mathrm{CH}_{2}\right), 4.56(\mathrm{dd}, J=1.5$, $2.5 \mathrm{~Hz}, 1 \mathrm{H}, \mathrm{FcCH}), 4.37$ (s, 5H, Cp), 4.11 (dd, $J=1.5,2.5 \mathrm{~Hz}, 1 \mathrm{H}, \mathrm{FcCH}), 4.04$ (br s, $1 \mathrm{H}, \mathrm{CH}$ ), 3.97 (t, J = 2.56 Hz, 1H, FcCH), 3.38 (br s, 1H, CH), 1.46 (br $\left.\mathrm{s}, 6 \mathrm{H}, 2 \times \mathrm{CH}_{3}\right), 1.04\left(\mathrm{brs}, 6 \mathrm{H}, 2 \times \mathrm{CH}_{3}\right)$.

${ }^{13} \mathrm{C}$ NMR (75.4 MHz, $\mathrm{CDCl}_{3}$ ): $\delta$ (ppm) 165.9 (C=Oester), $165.7\left(\mathrm{C}=\mathrm{O}_{\text {amide}}\right.$ ), 148.9 (ArC-O), 148.5 (ArC-O), $146.4 \quad(\mathrm{CH}=\mathrm{CH}=\mathrm{CH}=\mathrm{CH}=\mathrm{CO}), 141.3$ $(\mathrm{CH}=\mathrm{CH}=\mathrm{CH}=\mathrm{CH}=\mathrm{CO}), 130.7(\mathrm{ArC}), 124.6(\mathrm{CH}=\mathrm{CH}=\mathrm{CH}=\mathrm{CH}=\mathrm{CO}), 123.4$ $(\mathrm{CH}=\mathrm{CH}=\mathrm{CH}=\mathrm{CH}=\mathrm{CO}), 114.6(\mathrm{FcC}-\mathrm{CO}), 108.8(\mathrm{ArCH}), 106.2(\mathrm{ArCH}), 101.6$ $\left(\mathrm{CH}_{2}\right), 80.2(\mathrm{FcC}), 71.4(\mathrm{Cp}), 63.1(\mathrm{FcCH}), 62.1(\mathrm{FcCH}), 61.0(\mathrm{FcCH}), 50.7$ $(\mathrm{CH}), 46.0(\mathrm{CH}), 20.9\left(4 \mathrm{x} \mathrm{CH}_{3}\right)$.

\section{Acknowledgment}

This work was supported by the Université de Rennes 1 and CNRS. We gratefully acknowledge the Fonds Européen de Développement Régional (FEDER; D8 VENTURE Bruker AXS diffractometer) and Thermofisher (generous gift of 2,2,6,6-tetramethylpiperidine). W.E. would like to thank Prof. F. Mongin for support, critically reviewing this document and making valuable suggestions.

\section{References}

(1) (a) Ferrocenes: Homogeneous Catalysis, Organic Synthesis Materials Science, A. Togni, T. H., Ed. VCH: Weinheim, 1995; (b) Ferrocenes: Ligands, Materials and Biomolecules, Štěpnička, P., Ed. Wiley: Chichester, 2008; (c) Chiral Ferrocenes in Asymmetric Catalysis, L.-X. Dai, X.-L. H., Ed. Wiley-VCH: Weinheim, 2010; (d) Jaouen, G.; Vessieres, A.; Top, S. Chem. Soc. Rev. 2015, 44, 8802; (e)
Scottwell, S. Ø.; Crowley, J. D. Chem. Commun. 2016, 52, 2451; (f) Astruc, D. Eur. J. Inorg. Chem. 2017, 2017, 6; (g) Patra, M.; Gasser, G. Nature Reviews Chemistry 2017, 1, 0066.

(2) Schaarschmidt, D.; Lang, H. Organometallics 2013, 32, 5668.

(3) (a) Marquarding, D.; Klusacek, H.; Gokel, G.; Hoffmann, P.; Ugi, I. J. Am. Chem. Soc. 1970, 92, 5389; (b) Rebière, F.; Riant, O.; Ricard, L.; Kagan, H. B. Angew. Chem. Int. Ed. Engl. 1993, 32, 568; (c) Riant, O.; Samuel, 0.; Kagan, H. B. J. Am. Chem. Soc. 1993, 115, 5835; (d) Nishibayashi, Y.; Uemura, S. Synlett 1995, 1995, 79; (e) Richards, C. J.; Damalidis, T.; Hibbs, D. E.; Hursthouse, M. B. Synlett 1995, 1995, 74; (f) Sammakia, T.; Latham, H. A.; Schaad, D. R. J. Org. Chem. 1995, 60, 10; (g) Riant, 0.; Samuel, O.; Flessner, T.; Taudien, S.; Kagan, H. B. J. Org. Chem. 1997, 62, 6733.

(4) Alba, A.-N. R.; Rios, R. Molecules 2009, 14, 4747.

(5) (a) Zhu, D.-Y.; Chen, P.; Xia, J.-B. ChemCatChem 2016, 8, 68; (b) Gao D.-W.; Gu, Q.; Zheng, C.; You, S.-L. Acc. Chem. Res. 2017, 50, 351; (c) Schmiel, D.; Butenschön, H. Organometallics 2017, 36, 4979; (d) Kong, W.-J.; Shao, Q.; Li, M.-H.; Zhou, Z.-L.; Xu, H.; Dai, H.-X.; Yu, J.-Q. Organometallics 2018, 37, 2832.

(6) (a) Aratani, T.; Gonda, T.; Nozaki, H. Tetrahedron Lett. 1969, 10 , 2265; (b) Aratani, T.; Gonda, T.; Nozaki, H. Tetrahedron 1970, 26 , 5453; (c) Price, D.; Simpkins, N. S. Tetrahedron Lett. 1995, 36 6135; (d) Nishibayashi, Y.; Arikawa, Y.; Ohe, K.; Uemura, S. J. Org Chem. 1996, 61, 1172.

(7) Tsukazaki, M.; Tinkl, M.; Roglans, A.; Chapell, B. J.; Taylor, N. J.; Snieckus, V.J. Am. Chem. Soc. 1996, 118, 685.

(8) Firth, J. D.; Canipa, S. J.; Ferris, L.; O'Brien, P. Angew. Chem. Int. Ed. 2018, 57, 223.

(9) Genet, C.; Canipa, S. J.; O'Brien, P.; Taylor, S. J. Am. Chem. Soc. 2006, $128,9336$.

(10) Touafek, O.; Kabouche, A.; Kabouche, Z. Journal of Chemical Research 2000, 2000, 499.

(11) Tezuka, N.; Shimojo, K.; Hirano, K.; Komagawa, S.; Yoshida, K.; Wang, C.; Miyamoto, K.; Saito, T.; Takita, R.; Uchiyama, M. J. Am. Chem. Soc. 2016, 138, 9166.

(12) Dayaker, G.; Tilly, D.; Chevallier, F.; Hilmersson, G.; Gros, P. C.; Mongin, F. Eur. J. Org. Chem. 2012, 2012, 6051.

(13) Tazi, M.; Erb, W.; Halauko, Y. S.; Ivashkevich, O. A.; Matulis, V. E. Roisnel, T.; Dorcet, V.; Mongin, F. Organometallics 2017, 36, 4770.

(14) Sanders, R.; Mueller-Westerhoff, U. T. J. Organomet. Chem. 1996 $512,219$.

(15) Brikci-Nigassa, N. M.; Bentabed-Ababsa, G.; Erb, W.; Mongin, F. Synthesis 2018, 50, 3615.

(16) Dearden, M. J.; Firkin, C. R.; Hermet, J.-P. R.; O'Brien, P. J. Am. Chem Soc. 2002, 124, 11870

(17) (a) Schlosser, M. Angew. Chem. Int. Ed. 2005, 44, 376; (b) Schnurch M.; Spina, M.; Khan, A. F.; Mihovilovic, M. D.; Stanetty, P. Chem. Soc. Rev. 2007, 36, 1046; (c) Schnürch, M., Recent Progress on the Halogen Dance Reaction on Heterocycles. In Halogenated Heterocycles: Synthesis, Application and Environment, Iskra, J., Ed. Springer Berlin Heidelberg: Berlin, Heidelberg, 2012; pp 185; (d) Yamane, Y.; Sunahara, K.; Okano, K.; Mori, A. Org. Lett. 2018; (e) Erb, W.; Mongin, F. Tetrahedron 2016, 72, 4973; (f) Tazi, M.; Hedidi, M.; Erb, W.; Halauko, Y. S.; Ivashkevich, O. A.; Matulis, V. E.; Roisnel, T.; Dorcet, V.; Bentabed-Ababsa, G.; Mongin, F. Organometallics 2018, 37, 2207.

(18) Bhakuni, B. S.; Yadav, A.; Kumar, S.; Patel, S.; Sharma, S.; Kumar, S. J. Org. Chem. 2014, 79, 2944.

(19) Anderson, J. C.; Blake, A. J.; Arnall-Culliford, J. C. Org. Biomol. Chem 2003, 1, 3586

(20) (a) Barder, T. E.; Walker, S. D.; Martinelli, J. R.; Buchwald, S. L. J. Am Chem. Soc. 2005, 127, 4685; (b) Chen, W.-B.; Xing, C.-H.; Dong, J.; Hu, Q.-S. Adv. Synth. Catal. 2016, 358, 2072.

(21) Erb, W.; Hurvois, J.-P.; Roisnel, T.; Dorcet, V. Organometallics 2018, 37,3780

(22) Burchat, A. F.; Chong, J. M.; Nielsen, N. J. Organomet. Chem. 1997, 542,281 
(23) Singh, I. P.; Jain, S. K.; Kaur, A.; Singh, S.; Kumar, R.; Garg, P.; Sharma, S. S.; Arora, S. K. European Journal of Medicinal Chemistry 2010, 45, 3439.

(24) Breit, B.; Breuninger, D. Synthesis 2005, 2005, 2782. 